6 7 8 9 13 15

16

17

18

19

20

21

22

23

24

\title{
Experiments and Numerical Modelling of Microbially-Catalysed
} Denitrification Reactions

(a)

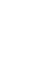

0

(1)

2

13

(1)

BRGM, 3 Avenue C. Guillemin, BP 36009, F-45060 Orléans Cedex 2, France

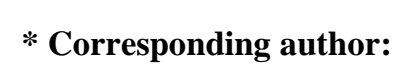

1.andre@brgm.fr

Tel : +33238643168

Fax : +33238643719

By L. André*, H. Pauwels, M.-C. Dictor, M. Parmentier, M. Azaroual,

(1)

Submitted to Chemical Geology

First submission December 2010

Revised manuscript April 2011 
Denitrification processes have been studied for many decades in both the laboratory and the field, and current work investigates heterotrophic and autotrophic denitrification reactions. Physical, chemical and microbiological parameters have been shown to control these degradation processes and the fate of nitrogen. In this paper, we describe results and modelling of denitrification reactions in batch and flow-through column experiments. The processes controlling the fate of nitrate and, more specifically, its reduction mediated by micro-organisms are explained in detail by a multi-step process. Modelling involves a rate law describing microbial respiration. Batch experiment data and the results of thermo-kinetic modelling of biogeochemical processes are in relatively good agreement, indicating that the coupled numerical approach is suitable for simulating each individual mechanism involved in denitrification phenomena. The calculated mass-balance indicates that about $40 \%$ of the carbon from acetate is used for anabolism and $60 \%$ for catabolism. The kinetic parameters estimated from the batch experiments are also suitable for reactive transport modelling of laboratory flow-through column experiments. In these experiments performed on pyritebearing schist, $80 \%$ of the nitrate reduction is attributed to heterotrophic micro-organisms and $20 \%$ to autotrophic bacteria. These results also indicate that for denitrification in the presence of acetate, the thermodynamic factor in the coupled thermodynamic/kinetic law can be disregarded and denitrification kinetics will be governed, for the most part, by electron donor/acceptor concentrations. This consistency between the results of closed and open systems is a prerequisite for the field-scale use of this type of numerical approach and the efficient and safe management of nitrogen sources. Breaking down the process into several steps makes it possible to focus on the main parameters that enhance the denitrification rate.

Keywords: denitrification; thermodynamic driving force; kinetics; micro-organisms

\section{Introduction}

60 Groundwater nitrate $\left(\mathrm{NO}_{3}{ }^{-}\right)$concentrations exceed human health criteria in many places as a result of anthropogenic inputs such as industrial emissions and synthetic fertilizers and manure used in agriculture (Squillace et al., 2002; McCallum et al., 2008; and references therein). Nitrate is now very commonly found in groundwater in Europe and North America (Matějů et al, 1992; Rivett et al, 2008). This creates environmental problems and has even led to the halting of pumping in many well fields. Techniques to decrease nitrate concentrations include ion exchange, reverse osmosis and biological denitrification (Matějů et al, 1992). 
Denitrification (or dissimilatory nitrate reduction) is recognised as being an efficient natural microbially-mediated nitrogen removal process in soils and waters (Dahab, 1987; Rivett et al., 2008; Aelion and Warttinger, 2010). Indeed, groundwater nitrate can be attenuated by denitrification processes that reduce $\mathrm{NO}_{3}{ }^{-}$according to a series of reactions mediated by micro-organisms under anaerobic conditions (Knowles, 1982; Tavares et al., 2006; Rivett et al., 2008):

$$
\mathrm{N}^{\mathrm{V}} \mathrm{O}_{3}^{-} \rightarrow \mathrm{N}^{\mathrm{III}} \mathrm{O}_{2}^{-} \rightarrow \mathrm{N}^{\mathrm{II}} \mathrm{O} \rightarrow \mathrm{N}_{2}^{\mathrm{I}} \mathrm{O} \rightarrow \mathrm{N}_{2}^{0}
$$

This has been widely observed in natural environments such as wetlands (Bowden, 1987; Whitmire and Hamilton, 2005; Scott et al., 2008), hyporheic zones (Duff and Triska, 1990; Jones et al., 1995; Sheibley et al., 2003) and shallow and deep aquifers (Lovley and Chapelle, 1995; Pauwels et al., 1998, 2010; Pinay and Burt, 2001; Molénat et al., 2002; Ruiz et al., 2002). Denitrification, with either heterotrophic (Her and Huang, 1995; Aslan, 2005) or autotrophic bacteria (Koenig and Liu, 2001; Park and Yoo, 2009), is also used to treat drinking water.

All of these nitrate bioremediation processes use denitrifying bacteria, which, like other micro-organisms in soil, water, sediments and oceans, play a major role in the biogeochemical cycles of major and trace elements (carbon, nitrogen, sulphur, phosphorus, iron, mercury, selenium, arsenic, etc.) (Dommergues and Mangenot, 1970; Stevenson and Cole, 1999; Madigan et al., 2000; Ehrlich, 2002). Most of these bacteria are able to use the energy of redox reactions to proliferate under aerobic or anaerobic conditions (Decker et al., 1970; Mitchell, 1961). They act as a catalyst for reactions in which electrons are transferred from a donor to an acceptor species. This microbial activity also links electron transfer to proton transfer through the cell membrane, enabling the synthesis of adenosine triphosphate (ATP) from adenosine diphosphate (ADP) and intracellular phosphate ions $\left(\mathrm{P}_{\mathrm{i}}\right)$. However, this reaction occurs only if the energy of the corresponding redox reaction is high enough to provide the energy for bacterial metabolism as an excess enthalpy (Jin and Bethke, 2002). Bacterial behaviour in natural aqueous systems is therefore closely linked to redox reactions (Lindberg and Runnels, 1984; Keating and Bahr, 1998; Michard, 2002).

These observations highlight the connexions between chemical and biological processes and the need to take into account a coupled thermodynamic/kinetic approach in order to accurately predict the global behaviour of such systems. Many theoretical and empirical approaches have 
100 been developed to describe biogeochemical processes. These include the enzyme reaction 101 kinetic model proposed by Michaelis and Menten (1913) and the bacterial growth kinetics model proposed by Monod (1949). The latter is used most often to describe the relationship between bacterial growth and substrate concentration (Rittmann and McCarty, 2001). This approach, while very successful for batch systems, has significant limitations. It is suitable for irreversible reactions and conditions far from thermodynamic equilibrium where chemical energy is not a limiting factor (Curtis, 2003; Jin and Bethke, 2007; Torres et al., 2010). It cannot, however, correctly predict reaction rates when substrate concentrations drop below a substrate threshold value (Lovley, 1985, Cord-Ruwisch et al., 1988; Giraldo-Gomez et al., 1992). Like other empirical rate laws, it does not consider that, close to thermodynamic equilibrium, there is not enough available energy to meet the needs of micro-organisms for microbial metabolism, maintenance and other cellular functions (Jin and Bethke, 2007).

113 Because of the large number and the complexity of the elementary mechanisms involved, the numerical modelling of these processes requires the use of powerful and relevant theoretical approaches in the calculation codes. To enable us to progress in our understanding of the biogeochemical behaviour of ecosystems, robust numerical tools must consider not only chemical and thermodynamic processes (i.e. Gibbs free enthalpy of the redox reactions), but also biological phenomena (i.e. bacterial growth). Among the various patterns proposed to simulate these coupled processes, that of Jin and Bethke $(2003,2005,2007)$ appears to be the most comprehensive because it considers both the chemical characteristics of the system (through electron donor/acceptor concentrations) and thermodynamic conditions (through the Gibbs free enthalpy of the redox reactions involved), which are the driving forces of the biogeochemical processes. The suitability of this approach (thereafter called "the Jin and Bethke approach") and the role of the thermodynamic potential factor have been demonstrated for degradation processes with the thermodynamic control of the respiration rate during arsenate reduction (Jin and Bethke, 2003), methanogenesis or sulfate reduction (Jin and Bethke, 2005). In these examples, the respiration process is expected to cease, even if significant amounts of both electron donors and acceptors are still available for metabolization. The role of thermodynamics has also been described concerning the progress of enzymatic reactions like benzoate, crotonate and glucose fermentations (Jin and Bethke, 2007). 
133 Because denitrification is a complex process mediated by micro-organisms, this coupled 134 thermokinetic/biogeochemical approach would seem to be highly suitable for simulating the 135 biogeochemical reactions occurring between nitrate and electron donors in water. Such a 136 model could be useful for the management of natural environments, particularly to estimate 137 denitrification rates in groundwater for long-term groundwater protection or for the 138 implementation of corrective measures to decrease the impact of diffuse sources. We describe 139 here a versatile model that does not oversimplify the biogeochemical system (overall reaction 140 of nitrate to $\mathrm{N}_{2}$ ) and is suitable for denitrification catalyzed by different microbial consortia. 141 This model includes a multi-step denitrification process that enables better control of the 142 numerous thermokinetic parameters involved by considering all reaction products. This model 143 tests the suitability of the Jin and Bethke approach for each individual mechanism (the 144 "driving forces" of each process). It defines the limiting and weight parameters and we use it 145 to investigate how natural consortia influence the dynamics of denitrification. The model also 146 enables integration of different microbial communities having specific influence on 147 denitrification process. This model allows for evaluation of the relationship between 148 anabolism and catabolism for the heterotrophic micro-organisms under consideration and it 149 enables estimation of the fraction of denitrification that is caused by autotrophic and/or 150 heterotrophic bacteria.

152 This work is based on laboratory denitrification experiments (batch and packed bed column 153 done with inoculum from groundwater that contains both heterotrophic and autotrophic 154 bacteria), and yields numerical simulations of the biogeochemical reactions involved in the 155 denitrification processes. Its objectives were to (i) identify the main steps that control the 156 kinetic rate of the denitrification process, (ii) highlight an approach using both batch and 157 flow-through column experiments, (iii) characterize the role played by micro-organisms 158 during each reaction, and (iv) develop a comprehensive biogeochemical model of 159 denitrification. 


\section{Experiments and Modelling}

167

168

169

170

171

172

173

174

175

176

177

178

179

180

181

182

183

184

185

186

187

188

189

190

191

192

193

194

195

196

\subsection{Experimental approach}

\subsubsection{Choice of experimental conditions}

Denitrification experiments conducted in this study were done with water and rock samples collected in the Coët-Dan catchment, $70 \mathrm{~km} \mathrm{SW}$ of Rennes (Brittany), in western France, where low nitrate concentrations in groundwater have been attributed to advanced denitrification mechanisms (Pauwels et al., 2001, 2010). The presence of pyrite in the aquifer rock contributes to a high-rate denitrification reaction (Pauwels et al., 1998) mediated by autotrophic bacteria according to the simplified reaction:

$$
5 \mathrm{FeS}_{2}+14 \mathrm{NO}_{3}{ }^{-}+4 \mathrm{H}^{+} \rightarrow 7 \mathrm{~N}_{2}+10 \mathrm{SO}_{4}{ }^{2-}+5 \mathrm{Fe}^{2+}+2 \mathrm{H}_{2} \mathrm{O}
$$

Heterotrophic denitrification involving organic matter has, however, also been reported (Pauwels et al., 2001, 2004).

Groundwater was collected with a submersible pump and stored in a sterile vessel after three well volumes of water had been purged. The well enabled the collection of water at a depth between 7 and $15 \mathrm{~m}$ - a redox zone where there is denitrification (Pauwels et al., 2001). Aliquots were filtered through $0.45 \mu \mathrm{m}$ pore size for chemical analysis. Aliquots for cation measurements were acidified to $\mathrm{pH} 2$. Alkalinity was measured by titration with $\mathrm{HCl}$. Major cation $\left(\mathrm{Na}^{+}, \mathrm{K}^{+}, \mathrm{Ca}^{2+}\right.$ and $\left.\mathrm{Mg}^{2+}\right)$ and anion $\left(\mathrm{NO}_{3}{ }^{-}, \mathrm{NO}_{2}{ }^{-}, \mathrm{Cl}^{-}\right.$and $\left.\mathrm{SO}_{4}{ }^{2-}\right)$ concentrations were measured by HPLC, and total iron by spectrophotometry. Dissolved organic C was measured by pyrolysis at $680{ }^{\circ} \mathrm{C}$ with $\mathrm{CO}_{2}$ infrared detection (TOC 5000 Shimadzu).

The bacterial analysis done on a raw groundwater sample with the "Most Probable Number" method (Halvorson and Ziegler, 1933) confirmed the presence of (i) heterotrophic denitrifying bacteria, (ii) Thiobacillus denitrificans (about 2,500 cells $\mathrm{mL}^{-1}$ ) and (iii) Acidithiobacillus ferrooxidans (fewer than 0.5 cells $\mathrm{mL}^{-1}$ ). Most of the population is able to reduce nitrate to nitrite (about 5,870 cells $\mathrm{mL}^{-1}$ ), whereas only a small fraction is able to reduce nitrate to $\mathrm{N}_{2}$ (about 130 cells $\mathrm{mL}^{-1}$ ). 
Only heterotrophic denitrification was considered for batch experiments, whereas by using schist, both heterotrophic and autotrophic processes were involved during the flow-through column experiment. Experiments were done in the presence of acetate (model organic compound). This enabled us to break down the global mechanism and quantify the kinetics of the various denitrification steps (Eqs. 2 to 4 ).

$$
\text { Step 1: } \mathrm{NO}_{3}^{-}+1 / 4 \mathrm{CH}_{3} \mathrm{COO}^{-}+1 / 4 \mathrm{H}^{+} \rightarrow \mathrm{NO}_{2}^{-}+1 / 2 \mathrm{CO}_{2(a q)}+1 / 2 \mathrm{H}_{2} \mathrm{O}
$$

$$
\begin{array}{ll}
\text { Step 2: } & \mathrm{NO}_{2}^{-}+1 / 4 \mathrm{CH}_{3} \mathrm{COO}^{-}+5 / 4 \mathrm{H}^{+} \rightarrow 1 / 2 \mathrm{~N}_{2} \mathrm{O}+1 / 2 \mathrm{CO}_{2(a q)}+\mathrm{H}_{2} \mathrm{O} \\
\text { Step 3: } & \mathrm{N}_{2} \mathrm{O}+1 / 4 \mathrm{CH}_{3} \mathrm{COO}^{-}+1 / 4 \mathrm{H}^{+} \rightarrow \mathrm{N}_{2}+1 / 2 \mathrm{CO}_{2(a q)}+1 / 2 \mathrm{H}_{2} \mathrm{O}
\end{array}
$$

\subsubsection{Batch experiments}

Batch assays were done in glass serum flasks $(500 \mathrm{~mL})$ supplemented with $150 \mathrm{~mL}$ (biotic flasks) or $300 \mathrm{~mL}$ (abiotic flasks) of sampled groundwater (Table 1). The headspace was flushed with $\mathrm{CO}_{2}$ gas to remove oxygen from the flasks. $\mathrm{CO}_{2}$ was chosen instead of $\mathrm{N}_{2}$ or $\mathrm{CO}_{2}+\mathrm{N}_{2}$ mixtures in order to avoid a secondary nitrogen source in a nitrogen-enriched medium. The flasks were sterilised by autoclaving at $120{ }^{\circ} \mathrm{C}$ for 20 minutes. The biotic flasks were inoculated with $150 \mathrm{~mL}$ of non-sterile groundwater. Six flasks were prepared -3 biotic flasks and 3 abiotic flasks. Ten millilitres $(10 \mathrm{~mL})$ of a 3,000-mg $\mathrm{KNO}_{3} \mathrm{~L}^{-1}$ solution were added to the medium to give a final concentration of $50 \mathrm{mg} \mathrm{NO}_{3}^{-} \mathrm{L}^{-1}$ and $50 \mathrm{~mL}$ of a 1476.4$\mathrm{mg} \mathrm{Na} \mathrm{CH}_{3} \mathrm{COO} \mathrm{L}{ }^{-1}$ solution were added to give a final concentration of $50 \mathrm{mg}$ acetate $\mathrm{L}^{-1}$. A trace-element solution $(0.25 \mathrm{~mL})$ containing the following, in $\mathrm{mg} \mathrm{L}^{-1}$, was added to this: EDTA, 500; $\mathrm{MnSO}_{4}, \mathrm{H}_{2} \mathrm{O}, 2.6 ; \mathrm{FeSO}_{4}, 200 ; \mathrm{ZnSO}_{4}, 7 \mathrm{H}_{2} \mathrm{O}, 10 ; \mathrm{H}_{3} \mathrm{BO}_{3}, 30 ; \mathrm{CoCl}_{2}, 6 \mathrm{H}_{2} \mathrm{O}, 20$; $\mathrm{CuCl}_{2}, 2 \mathrm{H}_{2} \mathrm{O}, 1 ; \mathrm{NiSO}_{4}, 7 \mathrm{H}_{2} \mathrm{O}, 2.4$; and $\mathrm{Na}_{2} \mathrm{MoO}_{4}, 2 \mathrm{H}_{2} \mathrm{O}, 3$.

\section{Water and gas samples were collected at regular intervals to monitor the reaction.}

\subsubsection{Flow-through column experiment}

Denitrification was studied in a glass column (0.45 L) equipped with an external water jacket that maintained the temperature at $14{ }^{\circ} \mathrm{C}$ throughout the experiment (Fig. 1). The column had an internal diameter of $3.5 \mathrm{~cm}$ and was $32 \mathrm{~cm}$ high. It was packed with $599.3 \mathrm{~g}$ of crushed schist (200 $\mu \mathrm{m}$, see Table 2 for mineralogical assemblage) and sterilised 3 times at 24-hour intervals by autoclaving for 1 hour at $121^{\circ} \mathrm{C}$. 
After sterilisation, the column was inoculated with a denitrifying bacteria consortium specially prepared for this experiment. The enrichment culture, prepared with a groundwater sample, was made up in sterile $500 \mathrm{~mL}$ serum flasks containing a culture medium composed of $150 \mathrm{mg} \mathrm{L}^{-1}$ of $\mathrm{KNO}_{3}, 5.66 \mathrm{mg} \mathrm{L}^{-1}$ of Na-acetate and $1 \mathrm{~mL}$ of the trace-element solution described above. The $\mathrm{pH}$ of the medium was adjusted to 6.5 with a 1 molar $\mathrm{H}_{2} \mathrm{SO}_{4}$ solution. The serum flasks were then flushed with $\mathrm{N}_{2}$ gas to ensure anaerobic conditions. The enrichment culture was incubated for 3 weeks at $14 \pm 2{ }^{\circ} \mathrm{C}$. Aliquots were sampled periodically to monitor bacterial growth and the nitrate concentration in the flask.

The experiment was done with synthetic water prepared with chemicals reagents (Table 3). The nitrate-bearing solution was injected into the column after the inoculum solution for 200 hours in two phases:

- Phase 1 (between 0 and 100 hours). The column was fed continuously with synthetic solution 1 (Table 3 ) in the up-flow mode by an adjustable peristaltic pump (flow rate $=$ $\left.0.25 \mathrm{~mL} \mathrm{~min}^{-1}\right)$. The major element concentrations in the injected aqueous solution were similar to those of the groundwater (Table 1). Before it was injected into the column (Fig. 1), the synthetic medium was continuously sparged with $\mathrm{CO}_{2}$ gas and placed in a thermostatic chamber $\left(14^{\circ} \mathrm{C}\right)$.

- Phase 2 (between 100 and 200 hours). A carbon source (acetate) with a concentration of $10 \mathrm{mg} \mathrm{C} \mathrm{L}^{-1}$ (Table 3 ) was added to the synthetic solution 2.

An automatic sampler (Gilson) was connected to the outlet column in order to periodically collect water samples.

The hydrodynamic characteristics of the column were determined by injecting a conservative tracer, $\mathrm{NaBr}$, before the denitrification experiment began. A pulse of the tracer at a constant flow rate $\left(0.25 \mathrm{~mL} \mathrm{~min}^{-1}\right)$ was injected and the outlet concentration of bromide was monitored with time. Based on the bromide breakthrough curve, the mean residence time was estimated to be 12.5 hours. The dispersivity coefficient, $0.02 \mathrm{~m}$, was determined by modelling the flow transport with PHREEQC (Parkhurst and Appelo, 1999). A pore volume of $190 \mathrm{~cm}^{3}$, corresponding to a mean porosity of $35 \%$, was calculated from the residence time and the injection flow rate. 


\subsubsection{Analytical procedure}

256 Nitrate, nitrite and acetate concentrations were determined during the batch and flow-through

257 column experiments by ion chromatography with a DIONEX IC3000-SP-EG-DC system

258 equipped with an AS50 autosampler and a conductimetric detector. A gradient elution with 259 sodium hydroxide, from 10 to $100 \mathrm{mM}$, was applied at $1 \mathrm{~mL} \mathrm{~min}^{-1}$ at $30{ }^{\circ} \mathrm{C}$ through an 260 anionic column (DIONEX-AG19 and AS19 HC, $4 \mathrm{~mm}$ ID). An aliquot was sampled for 261 bacteria counting using a Thoma cell by optic microscopy (Zeiss 400x). $\mathrm{N}_{2} \mathrm{O}$ in gas samples 262 was analysed with a chromatograph (VARIAN 3800) equipped with a gas injection valve and 263 an electron capture detector.

265 For the flow-through column experiment, the samples were collected in glass tubes previously 266 flushed with nitrogen and sealed. The tubes were opened in an anaerobic glove box for 267 analyses. One aliquot of raw sample was used for bacteria counting. pH and oxido-reduction 268 potential (ORP) were measured on the raw sample and the remaining water was filtered at $2690.45 \mu \mathrm{m}$ for anionic analyses $\left(\mathrm{NO}_{3}{ }^{-}, \mathrm{NO}_{2}^{-}, \mathrm{SO}_{4}{ }^{2-}, \mathrm{Cl}^{-}, \mathrm{CH}_{3} \mathrm{COO}^{-}\right)$by ion chromatography.

\subsection{Numerical modelling approach}

272 Micro-organisms affect the geochemical cycle of many chemical species by catalysing 273 chemical reactions while the physicochemical properties of the environment control the activities of micro-organisms by providing habitats, nutrients, and energy (Jin and Bethke, 2007). Physicochemical, thermodynamic/kinetic and biological phenomena must, therefore, be accurately predicted before we can determine the fate of chemical species (reactants and products), microbial population activity and microbial growth. Modelling requires a robust numerical model able to account for all of these strongly linked characteristics and the evolving properties.

\subsubsection{Thermodynamic and biological coupling}

281 Various kinetic rate laws and coupled models have been proposed to describe the thermo282 kinetics of bacterial growth (Hoh and Cord-Ruwisch, 1996; Fennel and Gossett, 1998; Hunter et al., 1998; Noguera et al., 1998; Kleerebezem and Stams, 2000; Knab et al., 2008). They are 284 all based on Monod's equation and often add terms containing a thermodynamic factor (such as the reaction quotient $\mathrm{Q} / \mathrm{K}$, where $\mathrm{Q}$ is the ionic activity product and $\mathrm{K}$ is the equilibrium 
constant of the reaction) or a minimum free energy $\left(\Delta \mathrm{G}_{\mathrm{min}}\right)$. However, most of these approaches were developed to describe specific physiological systems with constant $\Delta \mathrm{G}_{\text {min }}$ values. The approach proposed by Jin and Bethke (2002, 2003, 2005, 2007) goes further and seems to be more suitable and flexible because it associates (i) a kinetic factor for an electron donor, (ii) a kinetic factor for an electron acceptor, (iii) a term for bacterial growth, and (iv) a thermodynamic factor. Furthermore, the Jin and Bethke approach makes it possible to propose a consistent reactive transport model for hydro-geochemical systems with kinetically dissolving/precipitating minerals for which the reaction quotient $\mathrm{Q} / \mathrm{K}$ is used in the context of the Transition State Theory (Lasaga, 1984; Palandri and Kharaka, 2004).

The Jin and Bethke approach is based on the relationship between chemical redox reactions and microbial growth under natural conditions. Redox reactions, which are often slow, can, in some rare cases, be at thermodynamic equilibrium or close to it (Lindberg and Runnels, 1984; Keating and Bahr, 1998; Michard, 2002; Stefansson et al., 2005). In natural systems, the progress of redox reactions is usually catalysed by micro-organisms. During this process, bacteria use some of the released energy to synthesize adenosine triphosphate (ATP) from adenosine diphosphate (ADP) and the orthophosphate ion (intracellular $\mathrm{PO}_{4}{ }^{3-}$, denoted $\mathrm{P}_{\mathrm{i}}$ ) (Eq. 5):

$$
\sum_{\mathrm{D}} v_{\mathrm{D}} \mathrm{D}+\sum_{\mathrm{A}} v_{\mathrm{A}} \mathrm{A}+\mathrm{m} \mathrm{ADP}+\mathrm{mP} \mathrm{P}_{\mathrm{i}} \Leftrightarrow \sum_{\mathrm{D}^{+}} v_{\mathrm{D}^{+}} \mathrm{D}^{+}+\sum_{\mathrm{A}^{-}} v_{\mathrm{A}^{-}} \mathrm{A}^{-}+\mathrm{mATP}
$$

where $v_{D}, v_{A}, v_{D+}$ and $v_{A}$ - are the stoichiometric coefficients of chemical species $(D=$ donor, $\mathrm{A}=$ acceptor). The ATP serves as a chemical energy reserve (stock).

From this, Jin and Bethke (2002) derived a comprehensive kinetic law (Eq. 6) that can account quantitatively for the thermodynamic driving force of redox reactions:

$$
\mathrm{v}=\mathrm{k}[\mathrm{X}] \mathrm{F}_{\mathrm{D}} \mathrm{F}_{\mathrm{A}} \mathrm{F}_{\mathrm{T}}
$$

314 where $\mathrm{v}$ is the overall rate of microbial respiration $\left(\mathrm{mol} \mathrm{L}^{-1} \mathrm{~s}^{-1}\right), \mathrm{k}$ is the intrinsic kinetic 315 constant $\left(\mathrm{mol} \mathrm{g}^{-1} \mathrm{~s}^{-1}\right)$ and $[\mathrm{X}]$ is the biomass concentration $\left(\mathrm{g} \mathrm{L}^{-1}\right) . \mathrm{F}_{\mathrm{D}}$ and $\mathrm{F}_{\mathrm{A}}$ (ranging from 0 316 to 1 , dimensionless) are kinetic factors accounting for the effects of the concentration of dissolved chemical species involved in redox reactions (Eqs. 7 and 8): 


$$
\begin{aligned}
& \mathrm{F}_{\mathrm{D}}=\frac{\prod_{\mathrm{D}}[\mathrm{D}]^{\beta_{\mathrm{D}}}}{\prod_{\mathrm{D}}[\mathrm{D}]^{\beta_{\mathrm{D}}}+\mathrm{K}_{\mathrm{D}} \prod_{\mathrm{D}^{+}}\left[\mathrm{D}^{+}\right]^{\beta} \mathrm{D}^{+}} \\
& \mathrm{F}_{\mathrm{A}}=\frac{\prod_{\mathrm{A}}[\mathrm{A}]^{\beta_{\mathrm{A}}}}{\prod_{\mathrm{A}}[\mathrm{A}]^{\beta_{\mathrm{A}}}+\mathrm{K}_{\mathrm{A}} \prod_{\mathrm{A}^{-}}\left[\mathrm{A}^{-}\right]^{\beta} \mathrm{A}^{-}}
\end{aligned}
$$

where $\beta_{\mathrm{D}}, \beta_{\mathrm{A}}, \beta_{\mathrm{D}+}, \beta_{\mathrm{A}-}$ are exponents of reactant and product concentrations. Their values are not predicted by theory and depend on details of the electron transport mechanism (Jin and Bethke, 2003). $\mathrm{K}_{\mathrm{D}}$ and $\mathrm{K}_{\mathrm{A}}$ are constants for electron donor $\mathrm{D}$ and acceptor A.

$\mathrm{F}_{\mathrm{T}}$ (ranging from 0 to 1 , dimensionless) is the thermodynamic potential of the overall reaction corresponding to the driving force of the reaction (Eq. 9):

$$
\mathrm{F}_{\mathrm{T}}=1-\exp \left(\frac{\Delta \mathrm{G}_{\text {redox }}+\mathrm{m} \Delta \mathrm{G}_{\mathrm{P}}}{\chi \mathrm{RT}}\right)
$$

where $\Delta \mathrm{G}_{\text {redox }}$ is the free enthalpy of the reaction, $\Delta \mathrm{G}_{\mathrm{P}}$ is the phosphorylation energy, and $\chi$ is the average stoichiometric coefficient of the overall reaction. The coefficient $\mathrm{m}$ is the number of synthesised ATP defined in the overall reaction (Eq. 5).

\subsubsection{Numerical modelling approach}

The Jin and Bethke approach was included in the geochemical code PHREEQC (Parkhurst and Appelo, 1999) to deal with denitrification in the presence of acetate. This approach requires, however, that the database used by the calculation code be modified. In its standard use, this code is based on chemical equilibrium calculations of aqueous solutions interacting with minerals and gases using general and extended thermodynamic databases, and aqueous redox reactions are considered to be at equilibrium. As this is rarely the case (Stefansson et al., 2005), a kinetic term must be introduced for redox reactions. PHREEQC is a very flexible code for simulating chemical reactions in the aqueous phase and enables the re-writing of aqueous redox reactions to account for kinetic constraints. Since this study focuses on nitrate behaviour, all redox reactions involving nitrogen were re-written to take into account the kinetics of successive transformations (decreasing redox number: $\mathrm{N}(\mathrm{V}) \rightarrow \mathrm{N}(\mathrm{III}) \rightarrow \mathrm{N}(\mathrm{II}) \rightarrow \mathrm{N}(\mathrm{I})$ $\rightarrow \mathrm{N}(0)$ ). The chemical equilibria between nitrate-nitrite- $\mathrm{N}_{2} \mathrm{O}$ and $\mathrm{N}_{2}$ were removed from the 
database and replaced by kinetic laws. Only aqueous complexing reactions of nitrate and nitrite with cations and vapour-liquid equilibrium for $\mathrm{N}_{2} \mathrm{O}$ and $\mathrm{N}_{2}$ were kept.

\subsubsection{Thermo-kinetic simulation of denitrification processes}

348 The coupled thermodynamic-biogeochemical approach is applied to the reduction of (i) nitrate 349 to nitrite (Eq. 2), (ii) nitrite to nitrous oxide (Eq. 3) and (iii) nitrous oxide to nitrogen (Eq. 4). 350 These reactions are kinetically constrained, whereas thermodynamic equilibria are retained between all other species in the aqueous phase including nitrogen species (ligand) complexing cations. The term $\mathrm{F}_{\mathrm{T}}$ in Eq. (9) was determined based on the following assumptions. The phosphorylation enthalpy $\left(\Delta \mathrm{G}_{\mathrm{P}}\right)$ is roughly estimated to be $50 \mathrm{~kJ} \mathrm{~mol}^{-1}$ under typical physiological conditions (White, 1995), whereas $\chi$ and $\mathrm{m}$ are reaction-dependent parameters. For Eq. (2), $\chi=2$ and $\mathrm{m}=2 / 3$. Two protons are transferred by electron pairs and three are required for ATP synthesis (Jin and Bethke, 2005). For Eqs. (3) and (4), few data are available in the literature. Consequently, the same values for $\chi$ and $\mathrm{m}$ were used for the three reactions (Eqs. 2 to 4) (Q. Jin, personal communication, August 2009). Gibbs free enthalpies of each reaction $\left(\Delta \mathrm{G}_{\text {redox }}\right)$, determined at each time step from the free standard enthalpy of each reaction are $-140.12 \mathrm{~kJ} \mathrm{~mol}^{-1},-248.92 \mathrm{~kJ} \mathrm{~mol}^{-1}$ and $-314.43 \mathrm{~kJ} \mathrm{~mol}^{-1}$ for Eqs. (2) to (4), respectively (Michard, 2002).

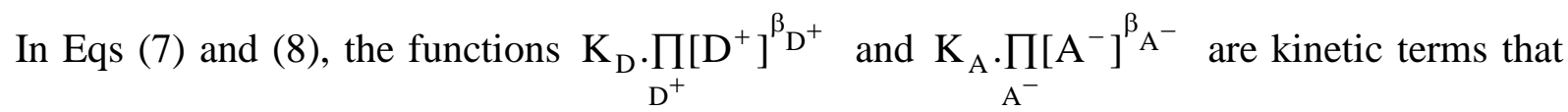
replace the half-saturation constant in the Monod equation. In a first approximation, the kinetic term can be expected to be equivalent to the half-saturation constant only when the thermodynamic potential is close to 1 (Jin and Bethke, 2005) or when, under appropriate geochemical conditions such as when the $\mathrm{pH}$ is buffered, there is a large substrate concentration and no build-up of metabolic products (Jin and Bethke, 2007). In this study, as demonstrated below, the $\mathrm{pH}$ is buffered and the thermodynamic factor is close to 1 throughout the reaction. Consequently, the two kinetic terms are replaced by two half-saturation constants $\left(\mathrm{K}_{\mathrm{D}}^{\prime}\right.$ and $\left.\mathrm{K}_{\mathrm{A}}{ }^{\mathrm{A}}\right)$. For step 1 of denitrification (Eq. 2), the values used are from Clément et al. (1997): $\mathrm{K}_{\mathrm{D}}{ }_{\mathrm{D}}=1.20 \mathrm{mg} \mathrm{L}^{-1}$ and $\mathrm{K}_{\mathrm{A}}{ }_{\mathrm{A}}=0.66 \mathrm{mg} \mathrm{L}^{-1}$. As no data are available for nitrite (Step 2 -

373 Eq. 3) or $\mathrm{N}_{2} \mathrm{O}$ (Step 3 - Eq. 4), we used the same values for $\mathrm{K}^{\prime}{ }_{\mathrm{A}}$ and $\mathrm{K}_{\mathrm{D}}{ }_{\mathrm{D}}$ as those determined 374 for nitrate. 
376 A growth yield of $0.13 \mathrm{mg}$-biomass $/ \mathrm{mg}-\mathrm{NO}_{3}{ }^{-}$(Clément et al., 1997) was used for step 1 (Eq. 377 2). For steps 2 and 3 (Eqs. 3 and 4), Clément et al. (1997) did not give a value for growth 378 yields. Values found in the literature indicate that the growth yield for nitrite is about three times that for nitrate (Peyton et al., 2001): a value of $0.40 \mathrm{mg}$-biomass $/ \mathrm{mg}^{-} \mathrm{NO}_{2}{ }^{-}$was therefore used. For nitrous oxide, as no literature data were found, the same value as the one for nitrate was chosen arbitrarily $\left(0.09 \mathrm{mg}\right.$-biomass $\left./ \mathrm{mg}^{-} \mathrm{N}_{2} \mathrm{O}\right)$. For calculations, a conversion factor of $6.210^{9}$ cells $\mathrm{mg}^{-1}$ biomass was used to convert experimental data (in cells $\mathrm{mL}^{-1}$ ) to input data for numerical model (in mg-biomass $\mathrm{mL}^{-1}$ ) (Clément et al., 1997).

Because denitrification by heterotrophic bacteria is studied, the model must also take into account the microbial growth using carbon from acetate and nitrogen from each nitrogenbearing species in solution. For the numerical simulations, the biomass is represented using a simplified generic form $\left(\mathrm{C}_{5} \mathrm{H}_{7} \mathrm{O}_{2} \mathrm{~N}\right)$ and integrated into Eqs. (2) to (4). The growth yield determined above provides information concerning the stoichiometry of the reaction, i.e. the number of moles of biomass synthesised from nitrate, nitrite and nitrous oxide consumption. Consequently, Eqs. (2) to (4) are rewritten:

392

$$
\mathrm{NO}_{3}^{-}+27 / 56 \mathrm{CH}_{3} \mathrm{COO}^{-}+31 / 56 \mathrm{H}^{+} \rightarrow 13 / 14 \mathrm{NO}_{2}^{-}+1 / 14 \mathrm{C}_{5} \mathrm{H}_{7} \mathrm{O}_{2} \mathrm{~N}+17 / 28 \mathrm{CO}_{2(a q)}+3 / 4 \mathrm{H}_{2} \mathrm{O}
$$

$$
\begin{aligned}
& \mathrm{NO}_{2}^{-}+11 / 20 \mathrm{CH}_{3} \mathrm{COO}^{-}+13 / 10 \mathrm{H}^{+} \rightarrow 9 / 20 \mathrm{~N}_{2} \mathrm{O}+1 / 10 \mathrm{C}_{5} \mathrm{H}_{7} \mathrm{O}_{2} \mathrm{~N}+3 / 5 \mathrm{CO}_{2(a q)}+5 / 4 \mathrm{H}_{2} \mathrm{O} \\
& \mathrm{N}_{2} \mathrm{O}+51 / 112 \mathrm{CH}_{3} \mathrm{COO}^{-}+51 / 112 \mathrm{H}^{+} \rightarrow 27 / 28 \mathrm{~N}_{2}+1 / 14 \mathrm{C}_{5} \mathrm{H}_{7} \mathrm{O}_{2} \mathrm{~N}+31 / 56 \mathrm{CO}_{2(a q)}+37 / 56 \mathrm{H}_{2} \mathrm{O}
\end{aligned}
$$

These stoichiometric equations, which take into account the biomass growth (anabolism), were incorporated in the geochemical code. Although bacterial death obviously also affects the micro-organism population during the experiments, it was disregarded. We assumed that no significant nutrients (or chemical components) coming from dead bacteria are released into solution. 


\section{RESULTS AND DISCUSSION}

404

405

406

407

408

409

410

411

412

413

414

415

416

417

418

419

420

421

422

423

424

425

426

427

428

429

430

431

432

\subsection{Batch experiments}

\subsubsection{N-species}

Batch experiments focused on measuring kinetic parameters for the entire denitrification reaction, from nitrate to $\mathrm{N}_{2}$. The abiotic flasks used as blanks show no denitrification during the entire experimental time. We know, therefore, that the nitrate attenuation observed in the biotic flasks is due to biological rather than chemical processes.

The results obtained on biotic flasks indicate a total denitrification in 40 days. Each experiment began with a period of about eight days during which the nitrate concentration did not vary (Fig. 2). Under our experimental conditions, micro-organisms seem to need time to adjust before denitrification begins. Nitrate reduction starts after 8 days with a decrease in nitrate correlated with the formation of nitrite in solution.

This first nitrate reduction reaction lasts about 30 days. At this time, nitrogen $(+\mathrm{V})$ has been completely reduced to nitrogen (+III) and nitrite is the major aqueous nitrogen species. Only small and transitory amounts of $\mathrm{N}_{2} \mathrm{O}$ are found in solution. Significant quantities of this species appear in solution when nitrite begins to be reduced by micro-organisms. The $\mathrm{N}_{2} \mathrm{O}$ concentration then increases steadily before $\mathrm{N}_{2}$ appears and nitrogen(I) is finally reduced to nitrogen(0).

Modelling is based on experimental constraints and the results obtained, using the Jin and Bethke approach, are described above. The kinetic constants for each reaction are:

- Nitrate to nitrite: An initial period (day 0 to day 8) during which no measurable microbial activity and no denitrification is recorded, is followed by a second period (day 8 to day 29) during which nitrate is reduced to nitrite consistent with a mean kinetic constant of $4.610^{-7}$ mol N L ${ }^{-1} h^{-1}$.

- Nitrite to nitrous oxide: A first period (day 0 to day 29), up to complete nitrate reduction, during which the nitrite reduction rate is assumed to be nil, is followed by a second period (day 30 to day 40) during which the nitrite reduction rate is about $2.310^{-7} \mathrm{~mol} \mathrm{~N} \mathrm{~L}^{-1} \mathrm{~h}^{-1}$. 
- Nitrous oxide to nitrogen: The kinetic rate is highly dependent on nitrate and nitrite concentrations. Up to the total reduction of nitrate (day 0 to day 29), the nitrous oxide reduction rate is assumed to be nil, whereas thereafter (day 29 to day 60), a value of $2.110^{-7} \mathrm{~mol} \mathrm{~N} \mathrm{~L}^{-1} \mathrm{~h}^{-1}$ provides a rather good fit of the observed results.

By coupling batch experiments and numerical modelling we were able to define the different steps of the denitrification process and determine the respective kinetic rates. The kinetic rate for the first reduction step (nitrate to nitrite) falls within the range reported in the literature (from $5.010^{-7}$ to $2.010^{-6}$ mol- $\mathrm{N} \mathrm{L}^{-1} \mathrm{~h}^{-1}$ ) for denitrification with organic matter (Star and Guillham, 1993; Schipper and Vojvodic Vukovic, 1998, 2000; Devlin et al., 2000). This experiment shows that the reduction of nitrite (and the formation of nitrous oxide) is related to nitrate consumption. As long as nitrate is present, nitrite increases and is measurable in solution. In natural environments, high nitrite concentrations are rarely observed, except in specific cases (Kelso et al., 1999). In laboratory systems, this nitrite accumulation is often observed by the use of acetate as the electron donor. Carbon sources such as acetate and propionate cause nitrite to accumulate in the medium, which does not occur with butyrate, valerate or coproate (Wilderer et al., 1987; van Rijn and Tal, 1996). These authors assume that in the presence of acetate, nitrite accumulation is caused by differences in nitrate and nitrite reduction rates and by the competition between nitrate and nitrite reduction pathways for electrons. Our experiments confirm this hypothesis of competition between the two reduction processes in the presence of acetate - nitrite reduction does not start until all of the nitrate has been consumed, favouring nitrate reduction before nitrite reduction and the nitrite accumulation.

\subsection{2 $\mathrm{pH}$ pattern}

The $\mathrm{pH}$ is initially stable or decreases slightly (during nitrate reduction to nitrite, up to day 29), and then increases during nitrite reduction (day 29 to day 40, Fig. 3). Calculated pH values fit the experimental data relatively well and the major trends are reproduced, except for some small discrepancies in the first part of the experiment. During nitrate reduction (Eq. 2), a small increase in $\mathrm{pH}$ is predicted by numerical calculations due to proton consumption, whereas experimental data show a slight decrease. The slopes of the curves for observed and simulated results are identical for the nitrite reduction reaction. Eq. (3) indicates that the proton consumption is higher than in the previous nitrate reduction reaction - the consequence of this being a change in the slope with a relatively greater increase in $\mathrm{pH}$ 
between day 30 and day 40 . However, $\mathrm{pH}$ does not vary greatly due to the buffering capacity of the reactive aqueous solution.

\subsubsection{Acetate as the electron donor}

Acetate is the electron donor used by micro-organisms to promote the heterotrophic denitrification reaction. The concentration is constant during the first 8 days (when no nitrate is consumed) and then decreases sharply (Fig. 4). After 40 days, there is no longer any acetate (for 2 of the 3 replicates). The simulation correctly fits the observed data, except for one of the replicates, for which no explication can be found, since all of the other measured variables (nitrogen species concentration, $\mathrm{pH}$, biomass concentration) are consistent for the three replicates. Numerical simulations confirm that all of the acetate is consumed during the experiment. It is used to synthesize $\mathrm{CO}_{2}$ (catabolism) and biomass (anabolism) (Eqs. 10 to 12). When numerical modelling was done without taking the bacteria anabolism into consideration (Fig. 4 - dashed line) only about $30 \mathrm{mg}$ of acetate are used to reduce $50 \mathrm{mg}$ of nitrate (Eqs. 2 to 4$)$.

Acetate is the source of both the electrons and the carbon needed by bacteria to proliferate. This is highlighted by the two simulations. One considers only catabolism, while the other takes into account both the anabolism and the catabolism of the micro-organisms (Fig. 4). Results using the first scenario do not match the measured acetate concentrations, whereas those using the second scenario agree with the observed acetate consumption data. This second scenario indicates that about $40 \%$ of the carbon from acetate is used for anabolism and $60 \%$ is used for catabolism. From Eqs. (10) to (12), the calculated mass-balance confirms that $41 \%$ of the carbon coming from acetate is used for biomass production, in agreement with literature data. For aerobic degraders, Greskowiak et al. (2005) proposed a value of $60 \%$ for anabolism, meaning that $40 \%$ of the carbon is converted to $\mathrm{CO}_{2}$. However, for anaerobic denitrification in the presence of acetate, this ratio is reversed. Clément et al. (1997) defined a biomass growth yield of about $20 \%$, whereas Odencrantz et al. (1990) and Istok et al. (2010) have proposed values of $37.5 \%$ and $41 \%$, respectively.

\subsubsection{Biomass growth}

Fig. 5 shows the evolution of the biomass in the batch experiment. The bacterial population increases rapidly (day 0 to day 8 ) before decreasing and then increasing once again. It stabilizes after 40 days (i.e. the end of nitrite reduction). The bacterial growth model, based on nitrate, nitrite and nitrous oxide reduction, produces results that are in relatively good 
agreement with experimental data. The overall trend and the final biomass concentration are 498 in agreement with observed data. The only discrepancy concerns the first period (day 0 to day 499 8). Some bacterial activity, independent of the denitrification process since nitrate reduction and acetate oxidation are nil (or extremely low) during this period, is assumed to influence the biomass population and probably $\mathrm{pH}$ during this period. The batch experiments were done with groundwater initially containing both heterotrophic and autotrophic bacteria. Autotrophic bacteria (very active in the field) might develop during the experiment in the aqueous solution. These use the mineral carbon (bicarbonate), and their activity might explain the biomass peak and the slight decrease in $\mathrm{pH}$ (Fig. 3). This is hypothetical, however, and since it does not play a major role in the overall denitrification process, it was disregarded in the numerical calculations.

The measurements of biomass concentration in the three replicates also show that the bacterial growth stabilizes after 40 days, in correlation with the total consumption of electron donors and acceptors. Acetate and nitrate - rather than the bioavailability of other elements seem to be the limiting factors of bacterial activity. As an example, a simple calculation of the amount of phosphorus needed shows that, assuming a classical formulation $\Delta \mathrm{C}: \Delta \mathrm{N}: \Delta \mathrm{P} \approx 106: 16: 1$ for dry biomass (Sigg et al. 2000), a few $\mu \mathrm{mol} \mathrm{P} \mathrm{L}^{-1}$ are necessary to generate the concentrations of biomass measured in the three replicates. The calculated $\mathrm{P}$ concentration and the limit of quantification have the same order of magnitude. We therefore assume that the natural groundwater used for these experiments provides enough trace elements (such as phosphorus) for the growth of the bacterial community.

\subsubsection{Remarks on the Thermodynamic Potential Factor}

519 One objective of this study was to determine the relative weight of kinetic factors influencing global denitrification. The thermodynamic potential factor $\left(\mathrm{F}_{\mathrm{T}}\right)$ remains constant (and equal to 1) throughout the experiment (Figs. 6 and 7). For denitrification in the presence of acetate, the thermodynamic factor has no affect on denitrification. For step 1 (i.e. reduction from nitrate to nitrite - Eq. 2), the denitrification process is governed by the kinetic factor $\left(\mathrm{F}_{\mathrm{A}}\right)$ related to the electron acceptor concentration (i.e. nitrate), whereas for step 2 (i.e. reduction from nitrite to nitrous oxide - Eq. 3), the kinetics of denitrification is limited by $\mathrm{F}_{\mathrm{A}}$ (i.e. nitrite concentration) and mainly $\mathrm{F}_{\mathrm{D}}$ factors (i.e. acetate concentration). For denitrification in the presence of acetate (Figs. 6 and 7), the thermodynamic factor can be disregarded and the global kinetics of denitrification are governed mainly by the concentrations of electron donors/acceptors. The 
model proposed by Jin and Bethke is, however, entirely suitable for simulating bacteriamediated changes in the redox state of a complex biogeochemical system.

\subsection{Flow-through column experiment}

532 Flow-through column experiments should help us better understand the influence of flow on water chemistry, in particular on the denitrification process. Tarits et al. (2006) have demonstrated the influence of hydrodynamic factors on water chemistry. They point out that denitrification is activated by pumping in the aquifer. In columns and, more generally, in consolidated porous media, microbial communities can also develop in biofilms, creating locally variable redox conditions and processes (Yu and Bishop, 1998; Bishop and Yu, 1999). Our column experiment provides an opportunity to observe whether the denitrification kinetic rates determined using batch experiments are always valid and can be used as is in transport experiments. The breakthrough curves for nitrate and nitrite are given in Fig. 8 and for chloride and sulphate in Fig. 9.

The nitrate concentration increases until it reaches a constant value equal to the input concentration $\left(50 \mathrm{mg} \mathrm{L}^{-1}\right.$ ). The nitrite concentration is lower than $2 \mathrm{mg} \mathrm{L}^{-1}$ (Fig. 8). The synthetic solution 1 (Table 3) has lower chloride and sulphate concentrations than the inoculum solution initially introduced in the column. This explains the decrease in the outlet concentrations of these two ions during the first hours of the experiment (Fig. 9). Between 50 and 100 hours, the outlet concentrations for chloride, sulphate and nitrate are the same as the inlet concentrations: the system reaches a steady state. No denitrification occurs in the column during this period despite the presence of bacterial inoculum in the system and of pyrite in the schist (Table 2).

At time $=100$ hours, phase 2 of the experiment begins with the input of a carbon source. A solution containing nitrate $\left(50 \mathrm{mg} \mathrm{L}^{-1}\right)$, acetate $\left(10 \mathrm{mg} \mathrm{L}^{-1}\right)$ and sulphate $\left(33.78 \mathrm{mg} \mathrm{L}^{-1}\right)$ is injected into the column (synthetic solution 2, Table 3). The nitrate concentration at the outlet of the column decreases immediately and the nitrite concentration increases. About $50 \%$ of the injected nitrate has been reduced to nitrite and to reduced nitrogen species after 190 hours (Fig. 8). Nitrate removal is not in a steady state. It is more rapid between 100 and 130 hours than during the period between 130 and 200 hours. Nitrite concentrations followed the opposite trend with a sharp increase between 100 and 130 hours and a smoother variation thereafter (130 to 200 hours). The chloride concentration does not vary when the injected 
solution changes, whereas the sulphate concentration does. Since synthetic solution 2 contains

562 less sulphate than synthetic solution 1, a decrease in the sulphate concentration was expected.

563 Although a small drop was observed, the outlet concentration of this species was always 564 greater than the injected concentration, as opposed to what occurred during the previous phase 565 (0 to 100 hours). Sulphates are therefore produced within the column, and we conclude that 566 dissolved sulphates come from an interaction between the aqueous solution and minerals. 567 Considering the mineralogical assemblage of the constituting rock (pyrite-bearing schist), the 568 sulphur production is attributed to the dissolution/oxidation reaction of pyrite. During this 569 stage (100 to 200 hours), two electron donors impact on the denitrification process - acetate 570 (Eqs. 2 to 4 ) and pyrite (Eq. 1).

571 Based on the results of the column experiment, we assume that the bacterial inoculum used to colonize the schist was composed mainly of heterotrophic bacterial species. The specific medium, enriched in acetate and used to develop this inoculum, probably favours the growth of heterotrophic bacteria (Tranvik and Höfle, 1987), which have a specific growth rate higher than that of autotrophic micro-organisms (Tsai and Wu, 2005). Marchand and Silverstein (2002) also show that heterotrophic microbial growth could have an impact on the behaviour of autotrophic populations, in particular on the biological oxidation of pyrite. They suggest that the development of heterotrophic micro-organisms might inhibit the rate and the extent of sulphide mineral oxidation. This experiment highlights the major role played by heterotrophic bacteria in the denitrification process since it is initiated by the addition of organic matter to 581 the injected solution.

582 The absence of denitrification due to the oxidation of pyrite by nitrate during the first period 583 (0 to 100 hours) was not expected since microbial denitrification had been observed at the site 584 where the samples were collected (Pauwels et al., 1998). However, these authors did not specify whether the autotrophic micro-organisms were chemolithotrophic bacteria (which use inorganic carbon as a carbon source and non-carbon compounds as an electron source,

587 Chapelle 2001) or chemoorganotrophic bacteria (which use inorganic carbon as a carbon 588 source and carbon compounds as an electron source, Chapelle 2001). From field 589 measurements, they simply identified the preponderant role of autotrophic bacteria compared 590 to that of heterotrophic bacteria. The results of our experiment show that chemoorganotrophic 591 bacteria had been fostered by the acetate-enriched medium used to develop the inoculum, 592 whereas chemolithotrophic bacteria, probably present in the inoculum but in low numbers, 593 were not active enough to initiate the denitrification process. Consequently, the low 
population of chemolitotrophic micro-organisms and the absence of organic matter for

595 chemoorganotrophic bacteria prevented any decrease in the nitrate concentration during this 596 first period.

598 The column experiment was modelled with PHREEQC using a 1D column (discretised into 59910 sections, each $3 \mathrm{~cm}$ long) with hydrodynamic characteristics determined using the bromide 600 tracer (see paragraph 2.1.2). The simulation complies with the two-phase experiment: 601 injection of a nitrous solution without organic carbon (synthetic solution 1, Table 3) during 602 the first 100 hours, followed by injection of a nitrate/acetate solution (synthetic solution 2, 603 Table 3) from hour 100 to hour 200. A constant injection flow rate is imposed at the inlet of 604 the column and a Cauchy boundary condition is assumed at the outlet. A biomass concentration of $1.610^{7}$ cells $\mathrm{mL}^{-1}$ is assumed at the beginning at the experiment.

606 For the biogeochemical part of the simulation, the kinetic parameters determined in batch 607 systems with acetate were used without modification (Eqs. 10 to 12). However, in this flow608 through column experiment, the kinetic rate for reaction 1 (i.e. pyrite oxidation, Eq. 1) had to 609 be estimated (3.2 $10^{-7} \mathrm{~mol} \mathrm{~N} \mathrm{~L}^{-1} \mathrm{~h}^{-1}$ ) based on field data (Postma et al., 1991; Pauwels et al., 610 1998). To our knowledge, there is no literature data for the parameters used to calculate the 611 thermodynamic factor of reaction 1 (Eq. 1). Only the free enthalpy can be calculated: $-456 \mathrm{~kJ}$ $612 \mathrm{~mol}^{-1}$ (Michard, 2002). This value is high (of the same order of magnitude as that of acetate), 613 and in batch experiments it was demonstrated that the thermodynamic factor is close to 1 with 614 such a high $\Delta \mathrm{G}_{0}$. In a first approximation, for this calculation, the thermodynamic factor is 615 assumed to be 1. A Monod approach is then used for reaction 1 (Eq. 1). This is justified due to 616 the high free enthalpy of the reaction and the excess of pyrite in the schist (Pauwels et al., 617 1998).

618 The kinetic rates used for each reaction make it possible to reproduce the experimental values 619 for nitrate, nitrite (Fig. 8) and sulphate (Fig. 9). The outlet sulphate concentrations, calculated 620 from the inlet $\mathrm{SO}_{4}$ concentration and the number of moles of pyrite oxidized by nitrates 621 (Reaction 1, Eq. 1), are in good agreement with the observed data (Fig. 9). A small difference 622 between measured and calculated sulphate concentrations is observed at 120 hours. Numerical 623 modelling predicted a small peak in sulphate that is not observed. In the column experiment, 624 the autotrophic bacteria have a short time lag, which is not considered in the numerical 625 approach since the two bacterial processes (heterotrophic and autotrophic) are activated at the 
same time. This simultaneous activation might explain the punctual over-estimation of the sulphate concentration.

628 The numerical simulation of the second part of the experiment (between 100 and 200 hours) also confirms that the bacteria active in the column are, for the most part, heterotrophic since the outlet nitrate concentration starts to decrease when acetate is co-injected with nitrate.

631 However, heterotrophic denitrification alone cannot explain the measured decrease in the 632 nitrate concentration. Autotrophic denitrification must also be involved to match the observed 633 data. The two autotrophic processes (chemoorganotrophic and chemolithotrophic) are also assumed to be active in this experiment. Indeed, the addition in the injected solution of a carbon source (acetate) can activate the chemoorganotrophic mechanism. Moreover, heterotrophic bacteria produce alkalinity (mainly as dissolved $\mathrm{CO}_{2}$ ), due to acetate degradation for their catabolism. According to the reactions described in Eqs. (10) to (12), 1 mole of nitrate induces the formation of about 1.8 moles of $\mathrm{CO}_{2, \mathrm{aq}}$. This increase in alkalinity could explain the increased activity of chemolithotrophic bacteria. All of these processes are assumed to be active in the column experiment.

641 The absence of any source of organic matter, therefore, prevents the development of 642 chemoorganotrophic activity. The low alkalinity of the injected solution also stops the activity of chemolithotrophic bacteria. With the addition of acetate, the heterotrophic bacteria are activated and produce alkalinity, which is immediately used by chemolithotrophic microorganisms. We also assume that chemoorganotrophic bacteria are activated by the carbon availability. However, neither the data nor the model can explain the relative weight of each autotrophic community. This simultaneous heterotrophic/autotrophic denitrification has been

648 described for nitrate removal from high-nitrate wastewater (Gommers et al., 1988; 649 Aminzadeh et al., 2010). These authors emphasize the high efficiency of such a treatment, which enables the removal of sulphide, acetate and nitrate in natural and synthetic wastewater in fluidized bed reactors. Oh et al. (2002) calculated that the reduction of $1 \mathrm{mg}$ of nitrate nitrogen, with methanol, generates $3.57 \mathrm{mg}$ of $\mathrm{CaCO}_{3}$. According to these authors, the two

653 processes are linked and a lack of any organic source can decrease the performance of 654 denitrification treatment.

656 Modelling of both heterotrophic and autotrophic processes correctly reproduces the observed 657 outlet concentrations of nitrate, nitrite and sulphate. The outlet nitrate concentration after 200 
658 hours is close to $30 \mathrm{mg} \mathrm{L}^{-1}$ (for an inlet concentration of $50 \mathrm{mg} \mathrm{L}^{-1}$ ), which means that the two 659 species of bacteria are able to remove about $40 \%$ of the initial nitrate. A comparison of two 660 calculations (results not shown here), one done with and the other without considering the 661 autotrophic mechanism, indicates that $80 \%$ of the nitrate consumption is due to heterotrophic 662 denitrification and the remainder is due to autotrophic processes. The numerical results for the 663 nitrite concentration are in good agreement with the observed data. As the modelling 664 approach considers only the production of nitrite by the heterotrophic process, we deduce that 665 autotrophic denitrification does not release any nitrite into solution (or that the kinetic rate of 666 nitrite production equals the kinetic rate of nitrite consumption). This absence of nitrite 667 accumulation (via pyrite oxidation) has been observed in $\mathrm{NO}_{3}{ }^{-}$-reducing cultures (Van Beer, 2000; Weber et al., 2001).

670 The experimental results of this flow-through column experiment show no time lag when 671 acetate is injected into the column. In batch experiments, there is no heterotrophic microbial 672 activity during the first 8 days (Fig. 2). In the field, Pauwels et al. (1998) observed an 673 autotrophic metabolic lag of about 40 hours. The absence of a microbial adjustment period 674 can be attributed to the experimental protocol:

675 - During the first phase of the experiment (the first 100 hours), the microbial population was 676 accustomed to a $\mathrm{NO}_{3}{ }^{-}$-containing solution, thus limiting the beginning of microbial activity, when acetate was added.

678 - The flow rate through the column is low compared to the flow rate in field studies where 679 transport processes have a greater impact on denitrification (Pauwels et al., 1998). Moreover, 680 the column experiment is done using crushed schist. Consequently, the exchanges, the contact 681 surface and, therefore, the interactions between aqueous solution, mineral (in particular 682 pyrite) and micro-organisms are probably more favourable, decreasing the time lag.

683

684

\section{CONCLUSIONS}

This study focuses on heterotrophic and autotrophic denitrification processes, i.e. the reduction of nitrate $\left(\mathrm{NO}_{3}{ }^{-}\right)$to nitrogen $\left(\mathrm{N}_{2}\right)$. Although denitrification in soils and aquifers is studied extensively for water quality, diffuse pollution transfer, and remediation, there is still an on-going debate in the scientific community concerning the contribution of organic matter 
as an electron donor when other mineral electron donors (i.e. pyrite) are available. The main goals of this study were therefore:

- to better understand denitrification processes in complex systems (water-rock-organic matter-microorganisms) using experiments and numerical modelling of elementary processes and,

- to conceptualize numerical modelling based on a decoupled thermodynamic database that enables the integration of the new thermo-kinetic approach of Jin and Bethke (2002), clearly splitting available energy in terms of three driving forces, i.e. catabolism, anabolism and a surviving reserve.

This new, comprehensive thermokinetic rate law based on energetic approaches takes into consideration both the thermodynamic driving force and biogeochemical processes. This approach is applied successfully to the heterotrophic denitrification processes in the presence of acetate coupled with the autotrophic contribution based on pyrite oxidation.

The thermodynamic and kinetic parameters incorporated in the geochemical code PHREEQC reproduce the concentrations of nitrate-bearing species during the entire duration of the batch experiment. This computer code is robust enough to model the behaviour of chemical species (electron donor, electron acceptor, $\mathrm{pH}$, etc.), biological aspects (anabolism and catabolism of the biomass population) and energy conditions (thermodynamic factor linked to the reaction energy). The comparison of model and observed results confirms that each step of nitrate reduction in the presence of acetate is governed mainly by kinetic factors and not limited by thermodynamic constraints. The energies of the reactions (in the presence of an electron donor like acetate) are too high compared to the energy needed by micro-organisms to proliferate. Consequently, this factor is not limiting and nitrate reduction is complete if there is an excess of electron donors.

Nevertheless, although this thermodynamic approach is not useful for denitrification with acetate, it cannot be applied to all denitrification processes in the presence of other electron donors. The main factor influencing the thermodynamic factor is the free enthalpy of the reactions - the reactions with acetate and pyrite are very energetic (several hundreds of $\mathrm{kJ}$ $\mathrm{mol}^{-1}$ ) whereas the free standard enthalpy of reactions with goethite or amorphous iron hydroxides are low (several tens of $\mathrm{kJ} \mathrm{mol}^{-1}$ ). This approach should, therefore, be of value for dealing with denitrification involving goethite or amorphous oxides as electron donors. 
724 This work, which uses both batch and column experiments, shows that these two approaches are complementary. The kinetic data set determined at the batch scale (similar to literature data) is sufficiently well constrained to simulate nitrate, nitrite and biomass concentrations. The numerical simulations indicate that during the heterotrophic denitrification reaction, about $40 \%$ of the carbon from acetate is used for anabolism, whereas $60 \%$ is used for catabolism. Moreover, this set of parameters, fitted with results from batch experiments, can be successfully used to model the column experiment, a 1D system. The heterotrophic denitrification in the column and batch experiments can be explained by the same process, which is promising for application to field studies. Numerical modelling is therefore a useful tool for managing natural environments when the numerous thermo-kinetic parameters are

\section{4 known.}

\section{ACKNOWLEDGEMENT}

737

738

739

740

741

742

We thank C. Crouzet and S. Touzelet (BRGM/Metrology, Monitoring and Analysis Division) for their assistance with experiments and chemical analyses, and S. Kremer (BRGM/Water Division) for her help modifying geochemical databases. The authors also thank two anonymous reviewers for helpful comments and suggestions.

\section{REFERENCES}

Aelion, C.M., Warttinger, U., 2010. Low sulfide concentrations affect nitrate transformations in freshwater and saline coastal retention pond sediments. Soil Biol. Biochem., 41(4), 735-741.

Aminzadeh, B., Torabian, A., Azimi, A.A., Nabi Bidhendi, Gh.R., Mehrdadi, N., 2010. Salt inhibition effects on simultaneous heterotrophic/autotrophic denitrification of high nitrate wastewater. Int. J. Environ. Res., 4(2), 255-262.

Aslan, S., 2005. Combined removal of pesticides and nitrates in drinking waters using biodenitrification and sand filter system. Process Biochem., 40, 417-424.

Bishop, P.L., Yu, T., 1999. A microelectrode study of redox potential change in biofilms. Water Sci. Technol., 39(7), 179-185.

Bowden, W.B., 1987. The biogeochemistry of nitrogen in freshwater wetlands. Biogeochemistry, 4, 313-348. 
Chapelle, F.H., 2001. Ground-Water Microbiology and Geochemistry, $2^{\text {nd }}$ ed. New York: John Wiley and Sons.

Clément, T.P., Peyton, B.M., Skeen, R.S., Jennings, D.A., Petersen J.N., 1997. Microbial growth and transport in porous media under denitrification conditions: experiments and simulations. J. Cont. Hydrol., 24, 269-285.

Cord-Ruwisch, R., Seitz, H., Conrad, R., 1988. The capacity of hydrogenotrophic anaerobic bacteria to compete for traces of hydrogen depends on the redox potential of the terminal electron acceptor. Arch. Microbiol., 149, 350-357.

Curtis, G.P., 2003. Comparison of approaches for simulating reactive solute transport involving organic degradation reactions by multiple terminal electron acceptors. Computers and Geosciences, 29, 319-329.

Dahab, M.F., 1987. Treatment alternatives for nitrate contaminated groundwater supplies. J. Environ. Syst. 17, 65-75.

Decker, K., Jungermann, K., Thauer, R.K., 1970. Energy production in anerobic organism. Angew. Chem. Int. Ed. Engl. 9, 138-158.

Devlin, J.F., Eedy, R., Butler, B.J., 2000. The effects of electron donor and granular iron on nitrate transformation rates in sediments from a municipal water supply aquifer. $\mathrm{J}$. Cont. Hydrol., 46, 81-97.

Dommergues, Y., Mangenot, F., 1970. Ecologie microbienne du sol. Masson Ed., Paris, 783 pp.

Duff, J.H., Triska, F.J., 1990. Denitrification in sediments from the hyporheic zone adjacent to a small forested stream. Can. J. Fish. Aquat. Sci., 47, 1140-1147.

Ehrlich, H.L., 2002. Geomicrobiology. $4^{\text {th }}$ edition. New York: Marcel Dekker, 768 pp.

Fennell, D.E., Gossett, J.M., 1998. Modeling the production of and competition for hydrogen in a dechlorinating culture. Environ. Sci. Technol., 32, 2450-2460.

Giraldo-Gomez, E., Goodwin, S., Switzenbaum, M. 1992. Influence of mass transfer limitations on determination of the half saturation constant for hydrogen uptake in a mixed-culture $\mathrm{CH}_{4}$-producing enrichment. Biotechnol. Bioeng., 40, 768-769.

Gommers, P.J.F., Buleveld W., Zuijderwijk, F.J.M., Kuenen, J.G., 1988. Simultaneous sulfide and acetate oxidation in a denitrifying fluidized bed reactor-II. Measurements of activities and conversion. Wat. Res., 22(9), 1085-1092.

Greskowiak, J., Prommer, H., Vanderzalm, J., Pavelic, P., Dillon, P., 2005. Modeling of carbon cycling and biogeochemical changes during injection and recovery of reclaimed water at Bolivar, South Australia. Water Resour. Res., 41, W10418. 
Halvorson, H.O., Ziegler. N.R., 1933. Applications of statistics to problems in bacteriology. I. A means of determining bacterial population by the dilution method. J. Bacteriol., 25, 101-121.

Her, J.J., Huang, J.S., 1995. Influence of carbon source and $\mathrm{C} / \mathrm{N}$ ratio on nitrate/nitrite denitrification and carbon breakthrough. Bioresour. Technol., 54, 45-51.

Hoh, C.Y., Cord-Ruwisch, R., 1996. A practical kinetic model that considers end product inhibition in anaerobic digestion processes by including the equilibrium constant. Biotechnol. Bioengin. 51, 597-604.

Hunter, K.S., Wang, Y., Van Cappellen, P., 1998. Kinetic modeling of microbially-driven redox chemistry of subsurface environments: coupling transport, microbial metabolism and geochemistry. J. Hydrol., 209, 53-80.

Istok, J.D., Park, M., Michalsen, M., Spain, A.M., Krumholz, L.R., Liu, C., McKinley, J., Long, P., Roden, E., Peacock, A.D., Baldwin, B., 2010. A thermodynamically-based model for predicting microbial growth and community composition coupled to system geochemistry: Application to uranium bioreduction. J. Cont. Hydrol., 112, 1-14.

Jin, Q., Bethke, C.M., 2002. Kinetics of electron transfer through the respiratory chain. Biophys. J. 83, 1797-1808.

Jin, Q., Bethke, C.M., 2003. A new rate law describing microbial respiration. Appl. Env. Microb. 69, 2340-2348.

Jin, Q., Bethke, C.M., 2005. Predicting the rate of microbial respiration in geochemical environments. Geochim. Cosmochim. Acta 69, 1133-1143.

Jin, Q., Bethke, C.M., 2007. The thermodynamics and kinetics of microbial metabolism. Am. J. Sc., 307, 643-677.

Jones, J.B., Fishe,r S.G., Grimm, N.B., 1995. Nitrification in the hyporheic zone of a desert stream ecosystem. J. N. Am. Benthol. Soc., 14(2), 249-258.

Keating, E.H., Bahr, J.M., 1998. Reactive transport modeling of redox geochemistry: Approaches to chemical disequilibrium and reaction rate estimation at a site in northern Wisconsin. Water Resour. Res., 34, 3573-3584.

Kelso, B.H.L., Smith, R.V., Laughlin, R.J., 1999. Effects of carbon substrates on nitrite accumulation in freshwater sediments. Appl. Environ. Microbiol., 65(1), 61-66.

Kleerebezem, R., Stams, A.J.M., 2000. Kinetics of syntrophic cultures: a theoretical treatise on butyrate fermentation. Biotechnol. Bioengin., 67, 528-543. 
Knab, N.J., Dale, A.W., Lettmann, K., Fossing, H., Jørgensen, B.B., 2008. Thermodynamic and kinetic control on anaerobic oxidation of methane in marine sediments. Geochim. Cosmochim. Acta, 72, 3746-3757.

Knowles, R., 1982. Denitrification. Microb. Rev. 46, 43-70.

Koenig, A., Liu L.H., 2001. Kinetic model of autotrophic denitrification in sulphur packedbed reactors. Water Res., 35, 1969-1978.

Lindberg, R.D., Runnels, M.D., 1984. Ground water redox reactions: an analysis of equilibrium state applied to Eh measurements and geochemical modelling. Science $225,925-927$.

Lasaga, A.C., 1984. Chemical kinetics of water-rock interactions. J. Geophys. Res., 89, 40094025 .

Lovley, D.R. 1985. Minimum threshold for hydrogen metabolism in methanogenic bacteria. Appl. Environ. Microbiol., 49, 1530-1531.

Lovley, D.R., Chapelle, F.H., 1995. Deep subsurface microbial processes. Rev. Geophys., 3, $365-381$

McCallum, J.E., Ryan, M.C., Mayer, B., Rodvang, S.J., 2008. Mixing-induced groundwater denitrification beneath a manured field in southern Alberta, Canada. Appl. Geochem., 23(8), 2146-2155.

Madigan, M.T., Martinko J.M., Parker, J., 2000. Brock Biology of Microorganisms. $9^{\text {th }}$ edition. Prentice Hall, Upper Saddle River, NJ.

Marchand, E.A., Silverstein, J., 2002. Influence of heterotrophic microbial growth on biological oxidation of pyrite. Environ. Sci. Technol., 36, 5483-5490.

Matějů, V., Ćižinská, S., Krejćí, J., Janoch, T., 1992. Biological water denitrification - A review. Enzyme Microb. Technol., 14, 170-183.

Michaelis, L., Menten, M.L., 1913. Die Kinetik der Invertinwirkung. Biochemische Zeitschrift, 49, 333-369.

Michard, G., 2002. Chimie des eaux naturelles. Principe de Géochimie des Eaux. Editions PUBLISUD, $461 \mathrm{p}$.

Mitchell, P., 1961. Coupling of phosphorylation to electron and hydrogen transfer by a chemiosmotic type of mechanism. Nature, 191, 144-148.

Molénat, J., Durand, P., Gascuel-Odoux, C., Davy, P., Gruau, G., 2002. Mechanisms of nitrate transfer from soil to stream in an agricultural watershed of French Brittany. Wat. Air Soil Pollut., 133, 161-183.

Monod, J., 1949. The growth of bacterial cultures. Ann. Rev. Microbiol. 3, 371-393. 
Noguera, D.R., Brusseau, G.A., Rittmann, B.E., Stahl., D.A., 1998. Unified model describing the role of hydrogen in the growth of Desulfovibrio Vulgaris under different environmental conditions. Biotechnol. Bioengin. 59, 732-746.

Odencrantz, J.E., Bae, W., Valocchi, A.J., Rittmann, B.E., 1990. Stimulation of biologically active zones (BAZ's) in porous media by electron-acceptor injection. J. Cont. Hydrol., $6,37-52$.

Oh, S.E., Bum, M.S., Yoo, Y.B., Zubair, A., Kim, I.S., 2002. Nitrate removal by simultaneous sulfur utilizing autotrophic and heterotrophic denitrification under different organics and alkalinity conditions: batch experiments. Wat. Sci. Technol., 47(1), 237-244.

Palandri, J.L., Kharaka, Y.K, 2004. A compilation of rate parameters of water-mineral interaction kinetics for application to geochemical modeling: U.S. Geological Survey Water-Resources Investigations Report 04-1068.

Park, J.Y., Yoo, Y.J., 2009. Biological nitrate removal in industrial wastewater treatment: which electron donor we can choose. Appl. Microbiol. Biotechnol., 82, 415-429.

Parkhurst, D.L., Appelo C.A.J., 1999. User's guide to PHREEQC (version 2): A computer program for speciation, batch-reaction, one-dimensional transport, and inverse geochemical calculations. U.S. Geological Survey Water-Resources Investigations Report 99-4259, 312 p.

Pauwels, H., Kloppmann, W., Foucher, J-C., Martelat, A., Fritsche, V., 1998. Field tracer test for denitrification in a pyrite-bearing schist aquifer. Appl. Geochem. 13(6), 767-778.

Pauwels, H., Lachassagne, P., Bordenave, P., Foucher, J.-C., Martelat, A., 2001. Temporal variability of nitrate concentration in a schist aquifer and transfer to surface waters. Appl. Geochem. 16(6), 583-596.

Pauwels, H, Talbo, H., 2004 - Nitrates concentration in wetlands: assessing the contribution of different water bodies from anion concentrations. Water Research, 38, 1019-1025.

Pauwels, H., Ayraud, V., Aquilina, L., Molénat, J., 2010. The fate of nitrogen and sulfur in hard-rock aquifers as shown by sulfate-isotope tracing. Appl. Geochem. 25(1), 105115.

Peyton, B.M., Mormile, M.R., Petersen, J.N., 2001. Nitrate reduction with Halomonas Campisalis: kinetics of denitrification at pH 9 and 12.5\% NaCl. Water Res., 35, 4237 4242 .

Pinay, G., Burt, T.P., 2001. Nitrogen Control by Landscape Structures. Research Project 1997-2000, EC DGXII. Environment and Climate: ENV4-CT97-0395, February 2001. Final Report 1997-2000. 
889

890

891

892

893

894

895

896

897

898

899

900

901

902

903

904

905

906

907

908

909

910

911

912

913

914

915

916

917

918

919

920

921

922

Postma, D., Boesen, C., Kristiansen, H., Larsen F., 1991. Nitrate reduction in an unconfined sandy aquifer: water chemistry, reduction processes and geochemical modeling. Water Resour. Res. 27, 2027-2045.

Rittmann, B.E., McCarty, P.L., 2001. Environmental Biotechnology: Principles and Applications. McGraw-Hill Companies, Inc., New York (USA), 754 pp.

Rivett, M.O., Buss, S.R., Morgan, P., Smith, J.W.N., Bemment, C.D., 2008. Nitrate attenuation in groundwater: A review of biogeochemical controlling processes. Water Res., 42, 4215-4232.

Ruiz, L., Abiven, S., Durand, P., Martin, C., Vertes, F., Beaujouan, V., 2002. Effect on nitrate concentration in stream water of agricultural practices in small catchments in Brittany: I. Annual nitrogen budgets. Hydrol. Earth Syst. Sci. 6, 507-513.

Schipper, L., Vojvodic Vukovic, M., 1998. Nitrate Removal from Groundwater using a Denitrification Wall Amended with Sawdust: Field Trial. J. Environ. Qual. 27, 664668.

Schipper, L., Vojvodic Vukovic, M., 2000. Nitrate Removal from Groundwater and Denitrification Rates in a Porous Treatment wall Amended with Sawdust. Ecol. Eng. $14,269-278$.

Scott J.T., McCarthy, M.J., Gardner, W.S., Doyle, R.D., 2008. Denitrification, dissimilatory nitrate reduction to ammonium, and nitrogen fixation along a nitrate concentration gradient in a created freshwater wetland. Biogeochemistry, 87, 99-111.

Sheibley, R.W., Jackman, A.P., Duff, J.H., Triska, F.J., 2003. Numerical modeling of coupled nitrification-denitrification in sediment perfusion cores from the hyporheic zone of the Shingobee River, MN. Adv. Water Resour., 26(9), 977-987.Sigg , L., Behra, P., Stumm, W., 2000. Chimie des milieux aquatiques; chimie des eaux naturelles et des interfaces dans l'environnement, $3^{\text {rd }}$ ed. Paris: Dunod.

Squillace, P.J., Scott, J.C., Moran, M.J., Nolan, B.T., Kolpin, D.W., 2002. VOCs, pesticides, nitrate, and their mixtures in ground-water used for drinking water in the United States. Environ. Sci. Technol., 36, 1923-1930.

Starr, R.C., Gillham R.W., 1993. Denitrification and organic carbon availability in two aquifers. Ground Water, 31, 934-947.

Stefansson, A., Arnorsson, S. and Sveinbjörnsdottir, A.E., 2005. Redox reactions and potentials in natural waters at disequilibrium. Chem. Geol., 221, 289-311.

Stevenson, F.J., Cole, M.A., 1999. Cycles of soil: carbon, nitrogen, phosphorus, sulfur, micronutrients. $2^{\text {nd }}$ Edition, John Wiley and Sons, 427 pages. 
Tarits, C., Aquilina, L., Ayraud, V., Pauwels, H., Davy, P., Touchard, F. and Bour, O., 2006. Oxido-reduction sequence related to flux variations of groundwater from a fractured basement aquifer (Ploemeur area, France). Appl. Geochem., 21(1), 29-47.

Tavares, P, Pereira, A.S., Moura, J.J.G., Moura, I., 2006. Metalloenzymes of the denitrification pathway. J. Inorganic Biochem., 100, 2087-2100.

Torres, C.I., Marcus, A.K., Lee, H.-S., Parameswaran, P., Krajmalnik-Brown, R., Rittmann, B.E., 2010. A kinetic perspective on extracellular electron transfer by anode-respiring bacteria. FEMS Microbiol. Rev., 34, 3-17.

Tranvik, L.J., Höfle, M.G., 1987. Bacterial Growth in Mixed Cultures on Dissolved Organic Carbon from Humic and Clear Waters. Appl. Environ. Microbiol., 53(3): 482-488.

Tsai, Y.P., Wu, W.M., 2005. Estimating biomass of heterotrophic and autotrophic bacteria by our batch tests. Environ. Technol., 26(6), 601-614.

Van Beer, C.G.E.M., 2000. Redox processes active in denitrification. Chapter 12 in: Redox: fundamentals, processes and applications. Springer-Verlag Berlin Heidelberg NewYork, Inc, 110 Figures, 21 Tables.

Van Rijn, J., Tal, Y., 1996. Influence of volatile fatty acids on nitrite accumulation by a Pseudomonas stutzeri strain isolated from a denitrifying fluidized bad reactor. Appl. Environ. Microbiol., 62(7), 2615-2620.

Weber, K.A., Picardal, F.W., Roden, E.E., 2001. Microbially catalysed nitrate-dependent oxidation of biogenic solid-phase Fe(II) compounds. Environ. Sci. Technol., 35, 16441650.

Wilderer, P.A., Jones, W.L., Dau, U., 1987. Competition in denitrification systems affecting reduction rate and accumulation of nitrite. Water Res., 21(2), 239-245.

White, D., 1995. The physiology and biochemistry of prokaryotes. Oxford University Press, New York, N.Y.

Whitmire, S.L., Hamilton, S.K., 2005. Rapid removal of nitrate and sulfate in freshwater wetland sediments. J. Environ. Qual., 34, 2062-2071.

Yu, T., Bishop, P.L., 1998. Stratification of microbial metabolic processes and redox potential change in an aerobic biofilm studied using microelectrodes. Water Sci. Technol., 37(4), 195-198. 
957 Fig. 1. Schematic representation of the flow-through column

958 Fig. 2. Evolution with time of the concentration of N-bearing species. Symbols correspond to experimental data with error bars. Lines represent modelling results

Fig. 3. Evolution with time of $\mathrm{pH}$. Points and dashed lines correspond to measured data of the

962 Fig. 4. Evolution with time of acetate concentration. Points with dotted lines correspond to measured data of the three replicates . The bold lines represent calculated values: dashed bold line $=$ calculation without considering the bacterial anabolism; solid bold line $=$ calculation with anabolism and catabolism

966 Fig. 5. Evolution with time of biomass concentration. Points and dotted lines correspond to

Fig. 6. Variations of kinetic factors $\left(\mathrm{F}_{\mathrm{D}}, \mathrm{F}_{\mathrm{A}}\right)$ and the thermodynamic factor $\left(\mathrm{F}_{\mathrm{T}}\right)$ for nitrate reduction (Eq. 2) versus nitrate concentration

$970 \quad$ Fig. 7. Variations of kinetic factors $\left(\mathrm{F}_{\mathrm{D}}, \mathrm{F}_{\mathrm{A}}\right)$ and the thermodynamic factor $\left(\mathrm{F}_{\mathrm{T}}\right)$ for nitrite reduction (Eq. 3) versus time

972 Fig. 8. Nitrate and nitrite concentrations at the outlet of the column. Symbols represent experimental data and lines correspond to numerical simulation results.

974 Fig. 9. Evolution of sulphate and chloride concentrations. Symbols represent $\mathrm{Cl}^{-}$and $\mathrm{SO}_{4}^{--}$ concentrations in the aqueous solution at the outlet. Dashed and dotted lines correspond to $\mathrm{Cl}^{-}$and $\mathrm{SO}_{4}^{--}$concentrations in the solution at the inlet. The solid line represents calculated sulphate concentration at the outlet of the column. 
Double water

982

983

984

985

986

987

988

989

Synthetic

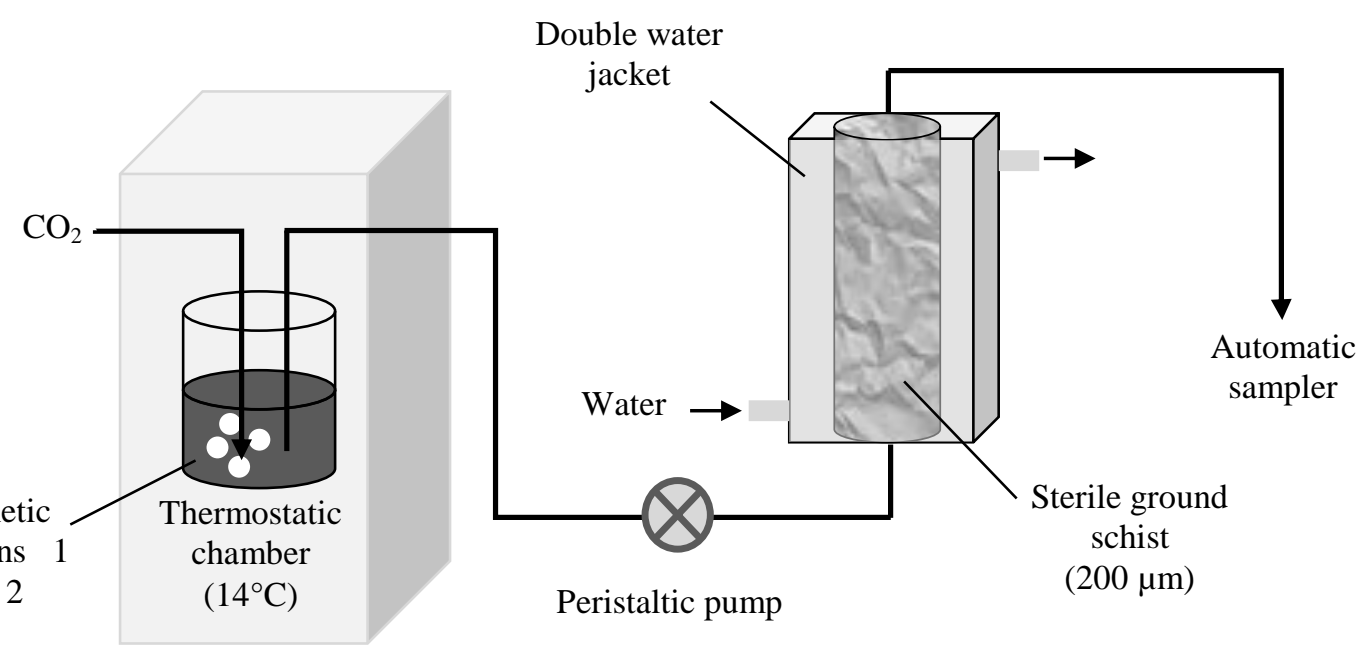

991 solutions

992

993

994

995

Fig. 1

996 


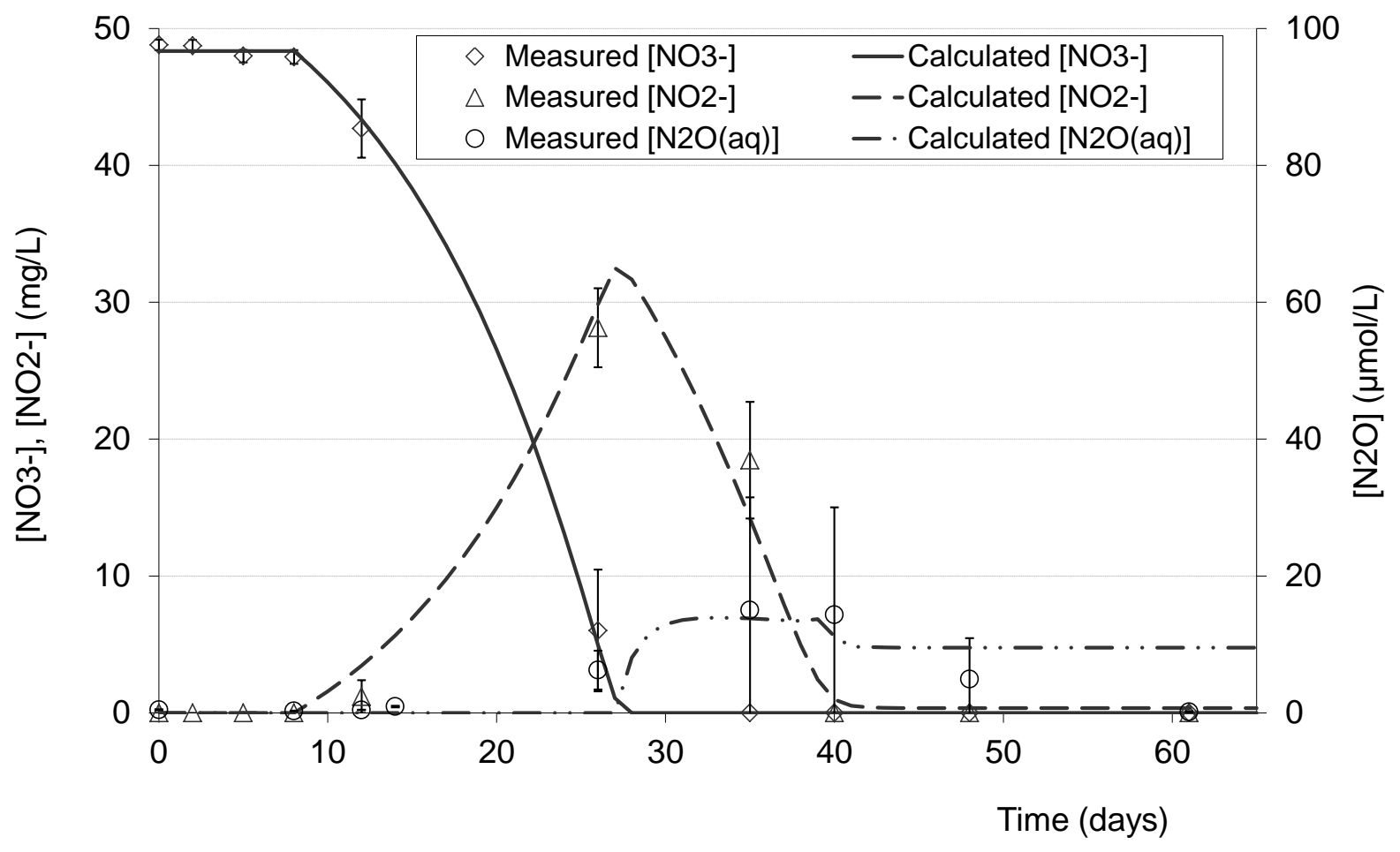

Fig. 2 


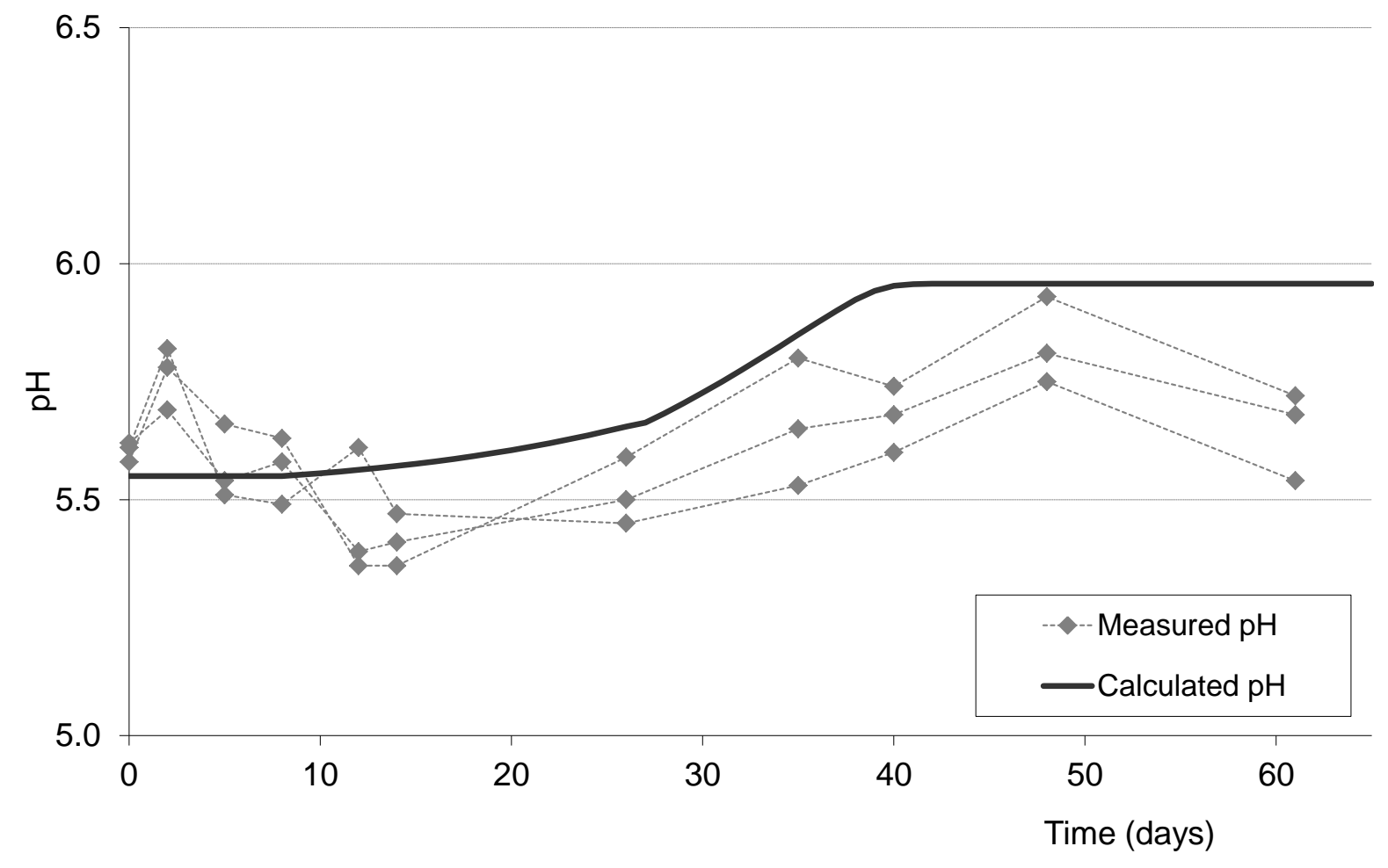

1000

1001

Fig. 3

1002

1003 


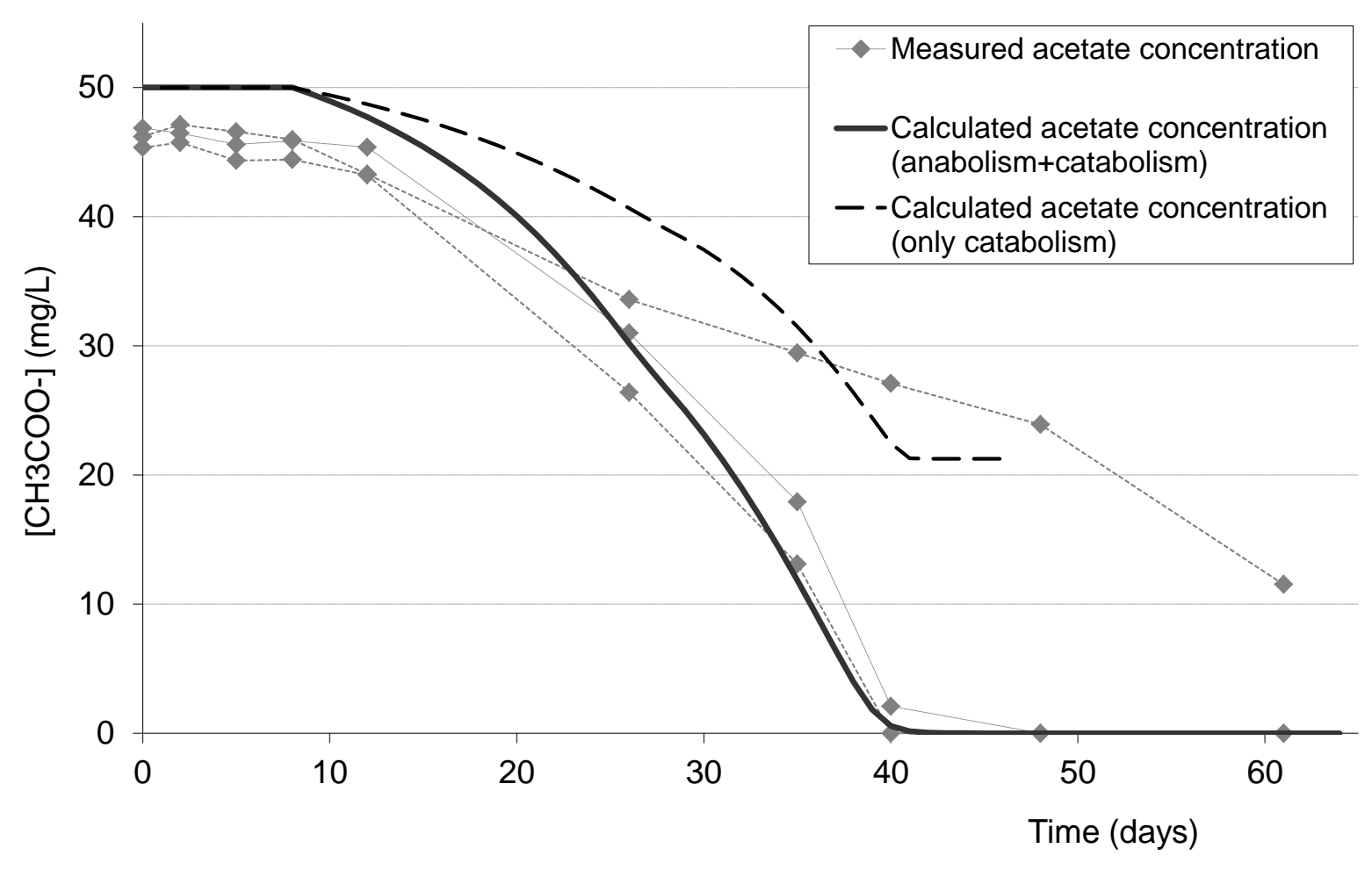

1004

1005

1006

Fig. 4

1007

1008 


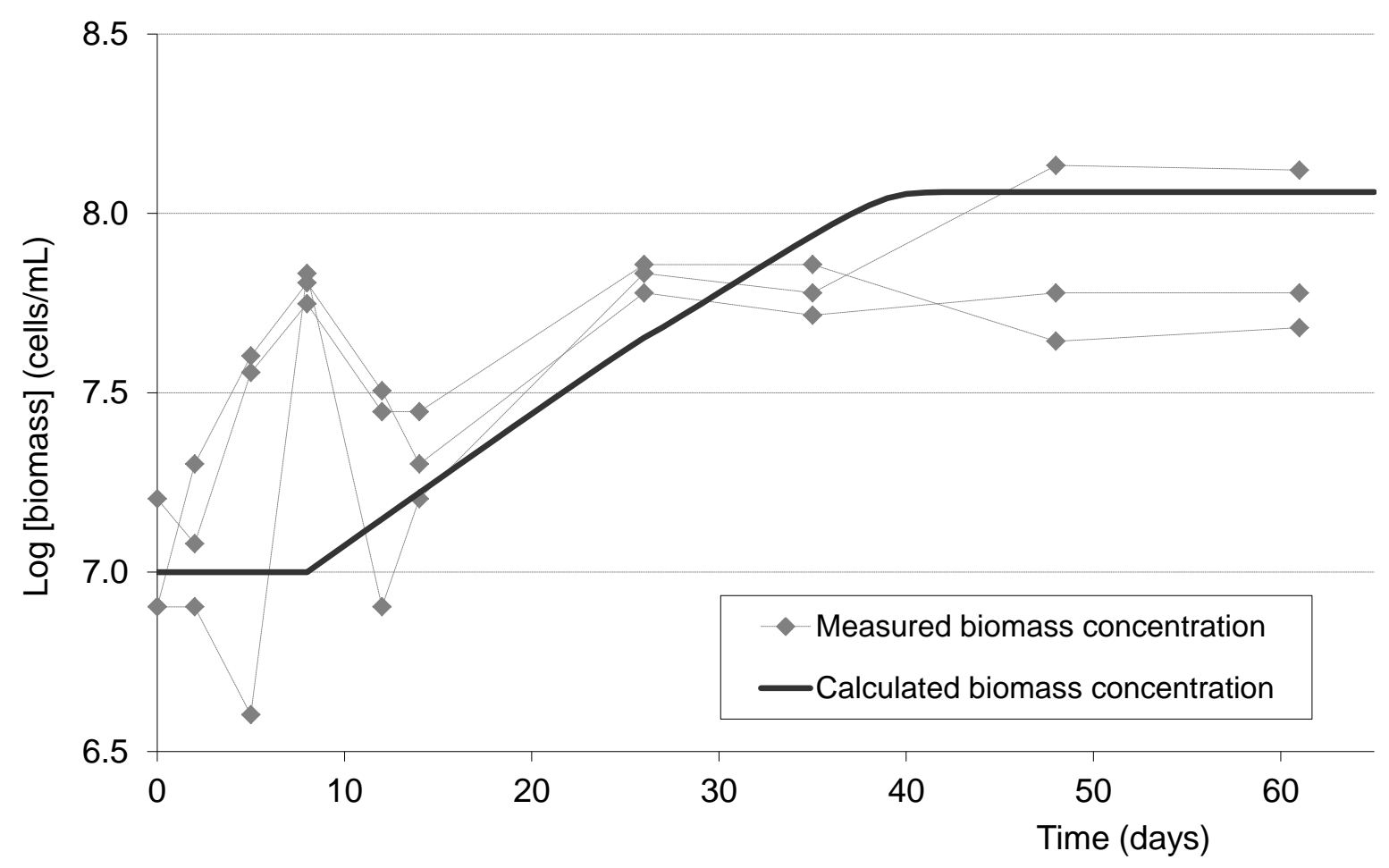

1009

1010

Fig. 5

1011

1012 


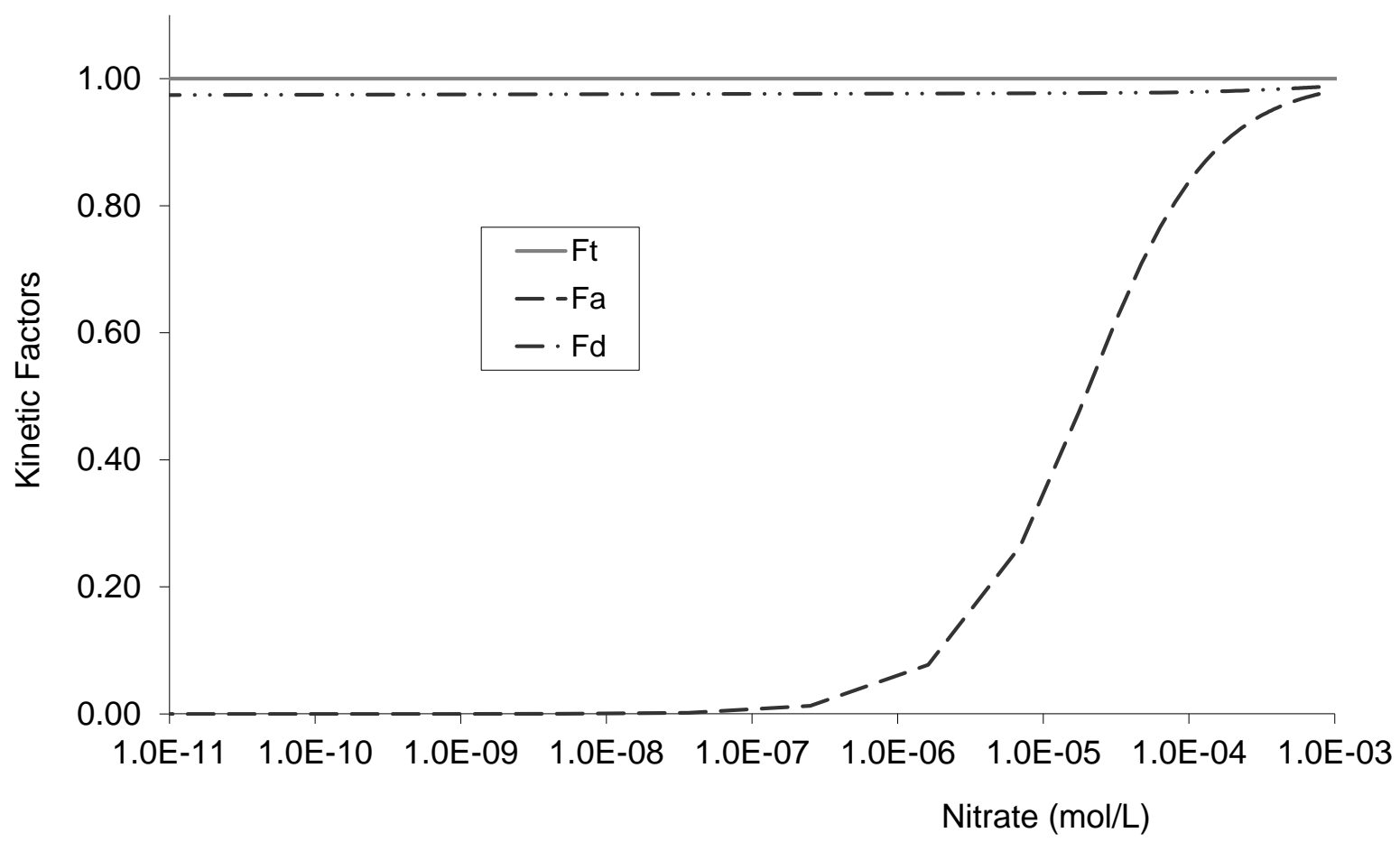

1013

1014

Fig. 6

1016 


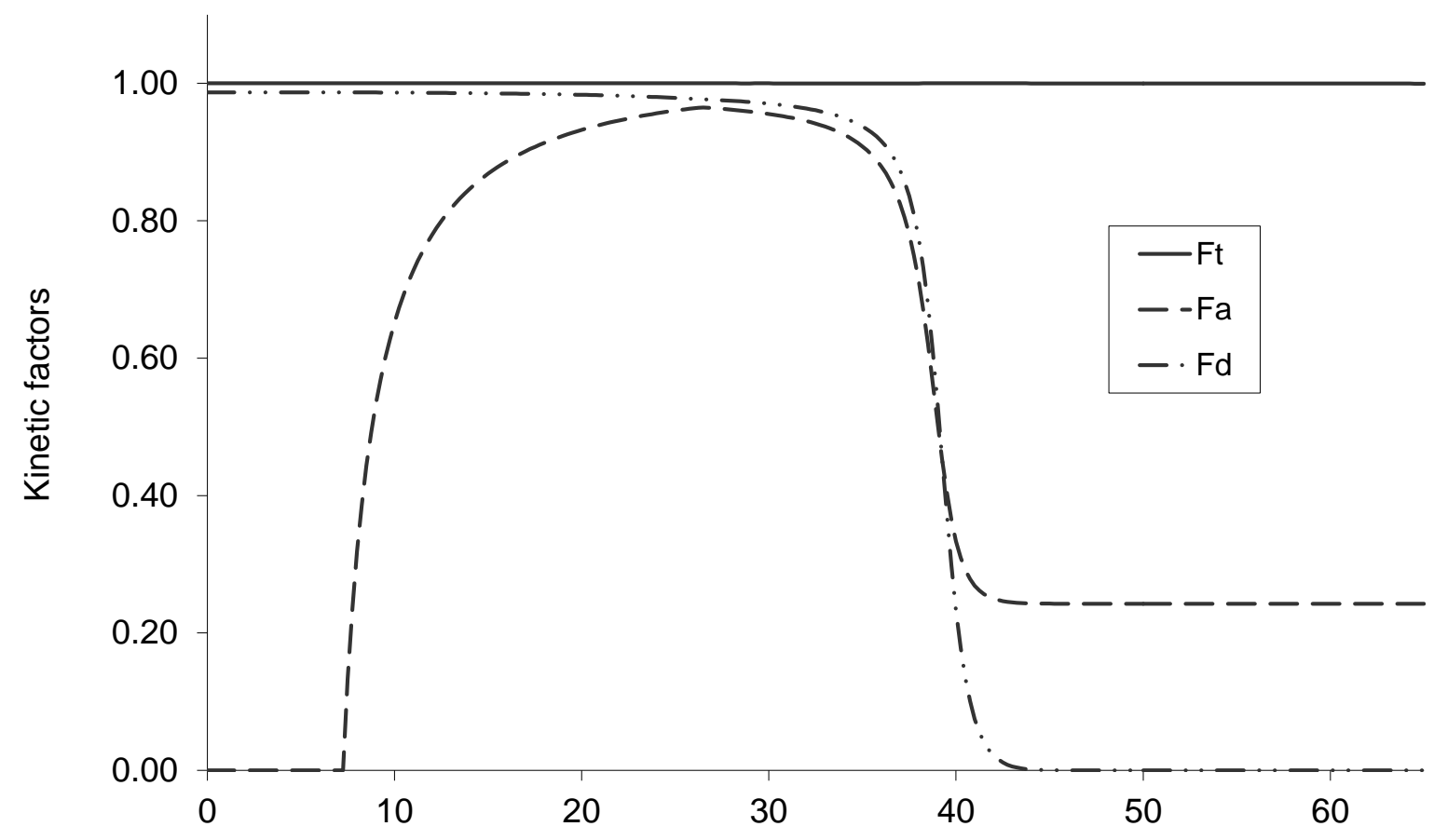

1017

1018

Time (days)

1019

Fig. 7

1020

1021 


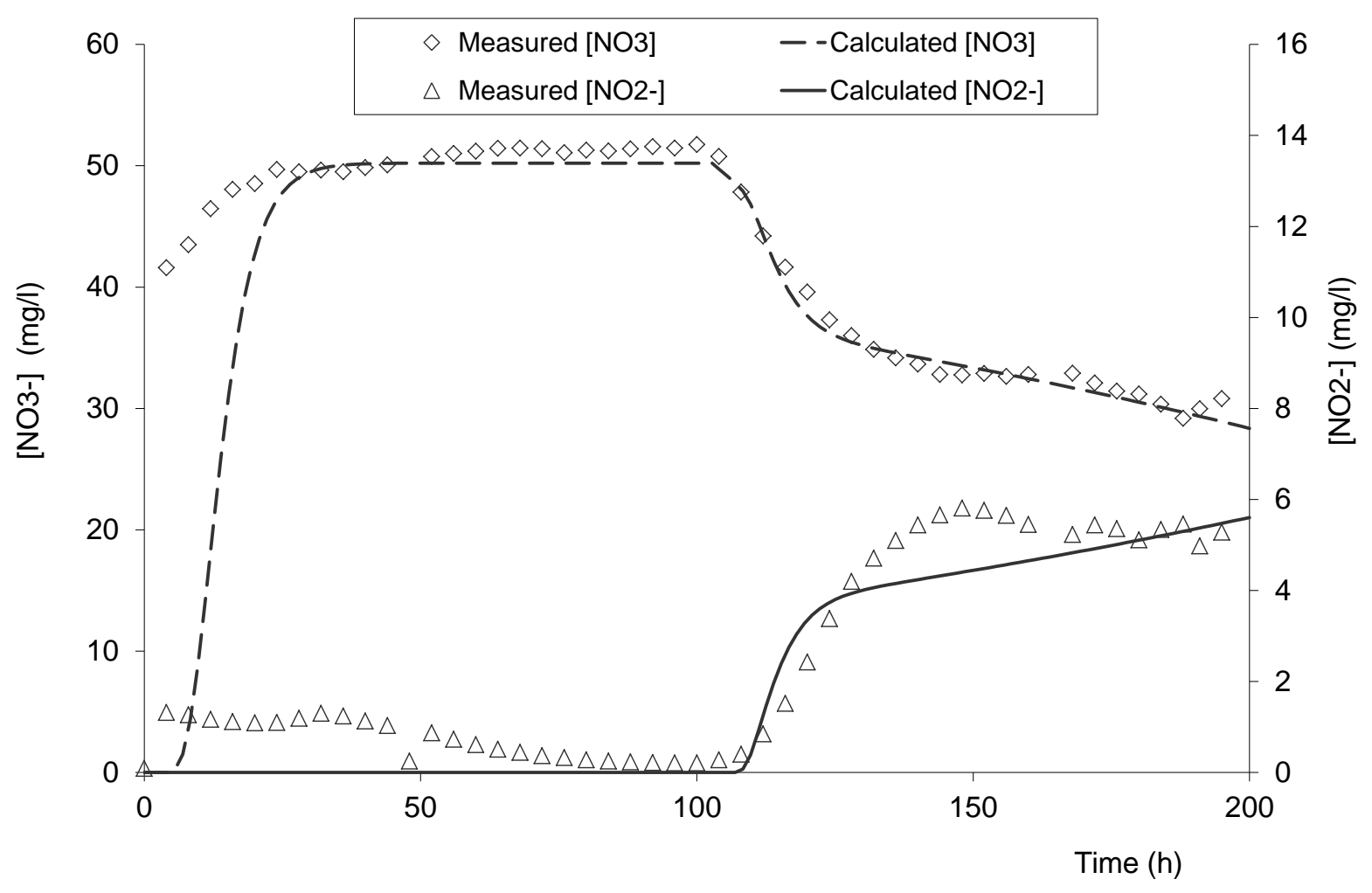

1022

1023

Fig. 8

1024

1025 


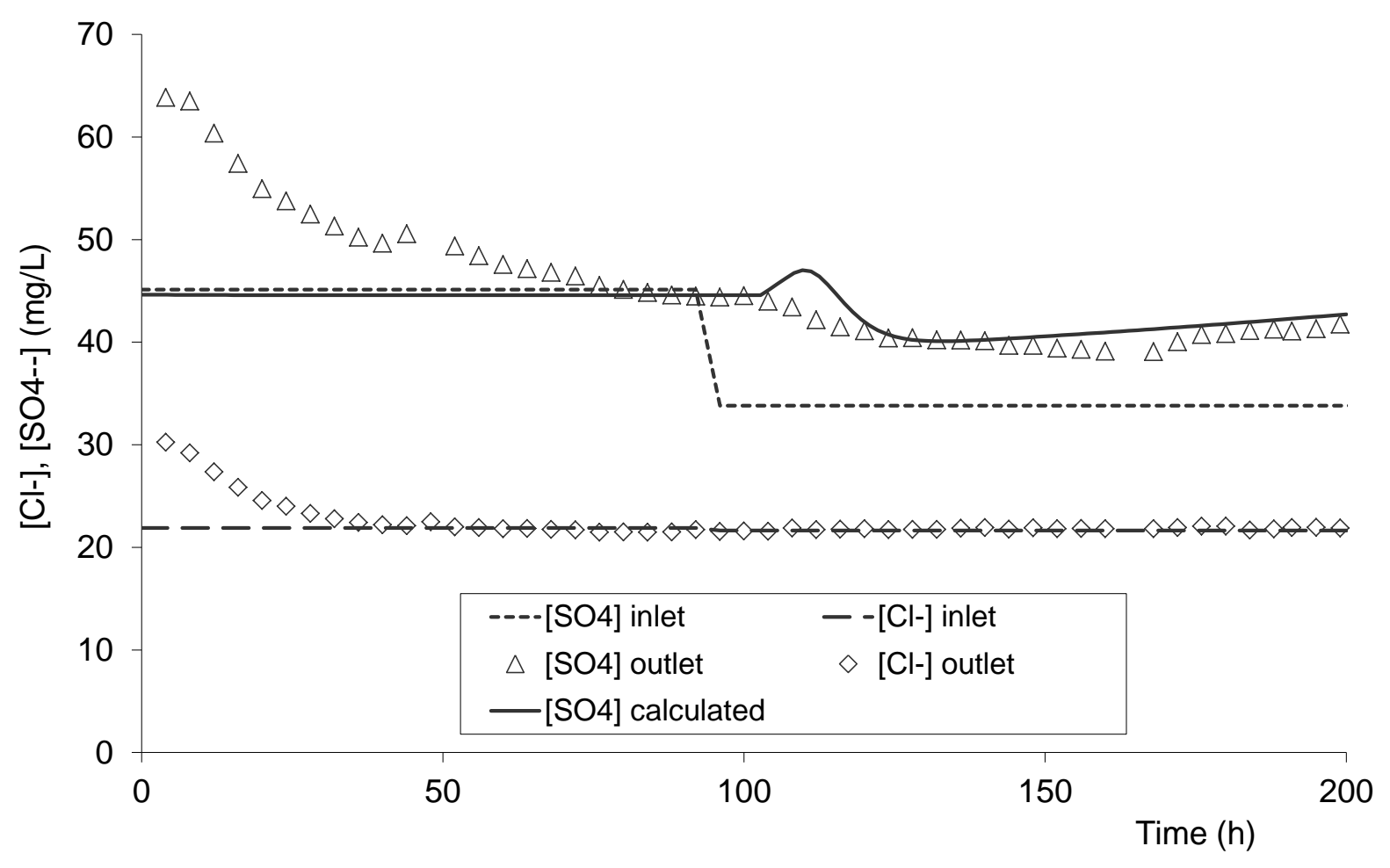

1026

Fig. 9

1028 
Table 1: Chemical composition of the groundwater (in mmol kg-1 ${ }_{\mathrm{H} 2 \mathrm{O}}$ )

\begin{tabular}{lccccccccccccc}
\hline Chemicals & $\mathrm{pH}$ & $\begin{array}{c}\mathrm{Eh} \\
(\mathrm{mV})\end{array}$ & $\mathrm{Alk}$ & $\mathrm{Ca}$ & $\mathrm{Mg}$ & $\mathrm{Na}$ & $\mathrm{K}$ & $\mathrm{Cl}$ & $\mathrm{NO}_{3}$ & $\mathrm{SO}_{4}$ & $\mathrm{Fe}$ & $\mathrm{DOC}$ \\
\hline Concentration & 6.68 & 179 & 0.77 & 0.38 & 0.36 & 0.80 & 0.03 & 0.78 & $<\mathrm{LOQ}$ & 0.33 & 0.13 & 0.058 \\
\hline
\end{tabular}

103

LOQ = Limit of Quantification

1032 
Table 2: Mineralogical composition of the aquifer formation

\begin{tabular}{lc}
\hline Minerals & Composition (in wt\%) \\
\hline Quartz & $20-25$ \\
Chlorite & $40-45$ \\
Mica / Illite & $30-35$ \\
Pyrite & 0.1 \\
Plagioclases & 5 \\
Orthose & 1 \\
Smectite & 0.5 \\
\hline
\end{tabular}

1034

1035

1036 
Table 3 Chemical compositions and concentrations of the synthetic solutions

\begin{tabular}{lcc}
\hline & \multicolumn{2}{c}{ Concentration $\left(\mathrm{mg} \mathrm{L}^{-1}\right)$} \\
\hline Chemical species & Synthetic solution 1 & Synthetic solution 2 \\
\hline $\mathrm{Ca}^{2+}$ & 11.60 & 11.60 \\
$\mathrm{Mg}^{2+}$ & 11.40 & 8.60 \\
$\mathrm{~K}^{+}$ & 1.10 & 1.10 \\
$\mathrm{Na}^{+}$ & 30.40 & 40.00 \\
$\mathrm{Cl}^{-}$ & 21.60 & 21.60 \\
$\mathrm{HCO}_{3}{ }^{-}$ & 30.50 & 30.50 \\
$\mathrm{SO}_{4}{ }^{-}$ & 45.10 & 33.80 \\
$\mathrm{NO}_{3}{ }^{-}$ & 50.00 & 50.00 \\
$\mathrm{CH}_{3} \mathrm{COO}^{-}$ & $/$ & 24.80 \\
\hline
\end{tabular}

1038

1039

1040

1041

1042

1043 